\title{
SCHEME OF MINERAL FACIES OF METAMORPHIC ROCKS AND ITS APPLICATION TO THE FENNOSCANDIAN SHIELD WITH REPRESENTATIVE SITES OF OROGENIC GOLD MINERALIZATION
}

\author{
S. A. Bushmin, V. A. Glebovitsky \\ Institute of Precambrian Geology and Geochronology RAS
}

\begin{abstract}
Our recent studies of metamorphism within the Fennoscandian (or Baltic) Shield area with representative sites of orogenic gold mineralization based on the scheme of mineral facies of metamorphic rocks introduced earlier inspired thorough revision of that scheme. The proposed scheme retains the commonly adopted nomenclature (prehnite-pumpellyite, greenschist, amphibolite, granulite, blueschist and eclogite facies) and is based on thermodynamic calculations and published empirical and experimental data on mineral equilibria in metapelitic and metamafic rocks.

We present two simplified maps of Archean and Proterozoic metamorphism, that offer good examples of the application of this improved scheme of metamorphic facies. The maps specify the prevailing metamorphic conditions and their relevant tectonic settings. Gold mineralization of economic interest is spatially associated with low-temperature lowpressure metamorphic terrains metamorphosed at the greenschist to low amphibolite facies of the andalusite-sillimanite facial series.
\end{abstract}

Ke ywords: metamorphic facies; metamorphism; mineral reaction; mineral paragenesis; P-T conditions; T/P gradient; orogenic gold; shear zone; accretionary orogen.

\section{С. А. БУшмин, В. А. Глебовицкий. СХЕМА МИНЕРАЛЬНЫХ ФАЦИЙ МЕТАМОРФИЧЕСКИХ ПОРОД И ЕЕ ПРИМЕНЕНИЕ К ТЕРРИТОРИИ ФЕННОСКАНДИНАВСКОГО ЩИТА С ПРОЯВЛЕНИЯМИ ЗОЛОТОРУДНОЙ МИНЕРАЛИЗАЦИИ ОРОГЕННОГО ТИПА}

В процессе исследования особенностей метаморфизма в районах Фенноскандинавского (или Балтийского) щита с проявлениями золоторудной минерализации орогенного типа частично изменена ранее предложенная схема минеральных фаций метаморфических пород. Предлагаемая новая схема, сохраняющая традиционные названия фаций (пренит-пумпеллиитовая, зеленосланцевая, амфиболитовая, гранулитовая, голубых сланцев, эклогитовая), основана на оригинальных термодинамических расчетах и опубликованных расчетных и экспериментальных данных по минеральным равновесиям в метапелитах и метабазитах и учитывает новые данные по метаморфизму изученной территории.

Статья сопровождается двумя упрощенными картами метаморфизма архейского и протерозойского возраста в качестве примера применения схемы метаморфических фаций при исследовании Р-Т условий метаморфизма и особенностей их пространственной локализации. Показано, что все промышленные проявления золотой минерализации орогенного типа расположены в зонах LT-LP метаморфизма от зеленосланцевой до низкотемпературной амфиболитовой фаций And-Sil фациальной серии. 
Ключе в ы е сло в а: метаморфическая фация; метаморфизм; минеральная реакция; минеральный парагенезис; Р-Т условия; Т/Р градиент; орогенное золото; сдвиговая зона; аккреционный ороген.

\section{Introduction}

Our study of metamorphism was focused on the Fennoscandian (or Baltic) Shield area with representative sites of orogenic gold mineralization (the term is according to [Groves et al., 1998]) and encompasses parts of the major tectonic units of the Fennoscandian Shield (Karelian craton, Svecofennian accretionary orogen, Belomorian-Lapland collision orogen). In the course of this study the scheme of mineral facies of metamorphic rocks introduced earlier by Bushmin and Glebovitsky [2008] was thoroughly revised. The paper is accompanied by two simplified maps of metamorphism of Archean and Proterozoic age as examples illustrating the application of the improved scheme of metamorphic facies to investigation of metamorphism. The abbreviations of minerals and other symbols used in this paper are listed in Table 1.

According to Eskola's facies concept [Eskola, 1920], the mineral composition of metamorphic rocks is a reflection of the external P-T conditions of metamorphism and the bulk rock chemistry. Thus, the variations in the mineral paragenesis at an unchanging bulk rock composition reflect changes in the P-T conditions. The term «mineral paragenesis» denotes sets of coeval equilibrium minerals. Mineral parageneses provide information on the physical-chemical conditions of metamorphism. Thus, metamorphic mineral facies/ subfacies (or just metamorphic facies/subfacies) define the P-T regions in which certain groups of metamorphic rocks are made up of certain mineral parageneses.

So far, various schemes of metamorphic mineral facies have been developed in P-T space [e. g. Fyfe, 1962; Dobretsov et al., 1970, 1972, 1974; Glebovitsky, 1973; Winkler, 1976; Glebovitsky, 1977; Korikovsky, 1979; Spear, 1993; Bushmin, Glebovitsky, 2008]. Mineral facies define mineral parageneses for various rock types and are based on petrogenetic grids that always pertain to certain chemical systems, e. g. KFMASH, etc. The main purpose of the schemes is to specify the relative position and PT-boundaries of mineral facies and subfacies. The areas of metamorphic rocks corresponding to certain mineral facies and subfacies shown in metamorphic maps will demonstrate the P-T conditions of metamorphism and the spatial distribution of these parameters.

The facies and subfacies are determined first of all using the compositions of metapelites and metabasites. Metapelites rich in potassium are most susceptible to variations in P-T conditions and are thus the potential source of the most detailed information about the conditions of metamorphism. Most researchers [e. g. Dobretsov et al., 1970; Glebovitsky, 1977; Spear, 1993; Berman et al., 2000; Bucher, Frey, 2002; Bushmin, Glebovitsky, 2008] consider similar mineral reactions as facies boundaries in metapelitic and metabasic rocks. These are so-called «key mineral reactions». The reasons for minor differences in positions of these reactions in P-T space are inconsistencies in the thermodynamic databases used in the calculations, variations in the water activity in the fluid, and the results of experiments.

The following mineral reactions are most commonly recognized as the temperature boundaries of metamorphic facies and subfacies in metapelites:

- kaolinite decomposition (a typical supergene mineral) with pyrophyllite formation

- first appearance of muscovite and chlorite, and then biotite and garnet (almandine)

- chloritoid decomposition and staurolite appearance

- staurolite decomposition

- muscovite decomposition with the formation of K-feldspar in parageneses with aluminum silicates (andalusite, sillimanite, kyanite); and the simultaneous appearance of migmatites

- biotite decomposition and orthopyroxene appearance, first in parageneses with $\mathrm{K}$-feldspar and then with $\mathrm{K}$-feldspar+cordierite

- appearance of the spinel+quartz and sapphirine+quartz parageneses.

The equilibria of $\mathrm{Al}_{2} \mathrm{SiO}_{5}$ polymorphs (kyanite, andalusite, and sillimanite) with the triple point at $\mathrm{P}=3.73 \mathrm{kbar}$ and $\mathrm{T}=506^{\circ} \mathrm{C}$ were calculated on the basis of the thermodynamic dataset compiled by Berman [1991] and Aranovich and Berman [1996]. These values are similar to experimental data: $\mathrm{P}=3.76 \mathrm{kbar}, \mathrm{T}=501^{\circ} \mathrm{C}$ [Holdaway, 1971]. The stability fields of andalusite, sillimanite, and kyanite are used to define pressure boundaries between both metamorphic facies/subfacies and the And-Sil (high thermal T/P gradient) and Ky-Sil (low thermal T/P gradient) metamorphic facies series. Mineral reactions in metapelites which cause the appearance or disappearance of, e. g., garnet+cordierite, orthopyroxene+sillimanite +quartz parageneses play the same role in defining the pressure boundaries. Another fact taken 
Table 1. Mineral abbreviations and other symbols

\begin{tabular}{|c|c|c|c|c|c|}
\hline Symbol & Full name & Symbol & Full name & Symbol & Full name \\
\hline$A b$ & Albite & Frs & Fersmite & $\mathrm{Phl}$ & Phlogopite \\
\hline Act & Actinolite & Fs & Ferrosillite & Phn & Phengite \\
\hline Adr & Andradite & Fsp & Feldspar & $\mathrm{PI}$ & Plagioclase \\
\hline Aeg & Aegirine & $\mathrm{Fu}$ & Fuchsite & Po & Pyrrhotite \\
\hline Alm & Almandine & Gd & Gedrite & Pre & Prehnite \\
\hline Als & Aluminium silicate & Ghn & Gahnite & $\mathrm{Prl}$ & Pyrophyllite \\
\hline Am & Amphibole & Gl & Glaucophane & Prp & Pyrope \\
\hline Ame & Amesite & Gn & Galena & Ps & Pistacite \\
\hline An & Anorthite & $\mathrm{Gr}$ & Garnet & Pum & Pumpellyite \\
\hline And & Andalusite & Grs & Grossular & Px & Pyroxene \\
\hline Ank & Ankerite & Gru & Grunerite & Py & Pyrite \\
\hline Ann & Annite & Gt & Graphite & Qu & Quartz \\
\hline Ant & Anthophyllite & $\mathrm{Hb}$ & Hornblende & $\mathrm{Rbd}$ & Rhabdophane \\
\hline Ap & Apatite & $\mathrm{Hd}$ & Hedenbergite & Rbk & Riebeckite \\
\hline Apy & Arsenopyrite & $\mathrm{He}$ & Hercynite & Rht & Richterite \\
\hline Ara & Aragonite & $\mathrm{HI}$ & Halite & Ro & Rhodonite \\
\hline Arf & Arfvedsonite & $\mathrm{Hm}$ & Hematite & Rpd & Ripidolite \\
\hline Atg & Antigorite & $\mathrm{Hq}$ & Holmquistite & Rsm & Rossmanite \\
\hline Aug & Augite & $\mathrm{Hs}$ & Hastingsite & Rt & Rutile \\
\hline $\mathrm{Bd}$ & Baddeleyite & $\mathrm{Hy}$ & Hypersthene & Sap & Sapphirine \\
\hline Bo & Bornite & Im & IImenite & Sch & Scheelite \\
\hline Bre & Breunnerite & Irt & IImenorutile & Scp & Scapolite \\
\hline Brr & Barroisite & Jd & Jadeite & Sid & Siderite \\
\hline Brt & Barite & $\mathrm{Ka}$ & Kaolinite & Sil & Sillimanite \\
\hline $\mathrm{Bt}$ & Biotite & Kfs & K-feldspar & Slc & Silica amorphous \\
\hline $\mathrm{Bz}$ & Bronzite & Kor & Kornerupine & Smt & Smithsonite \\
\hline Cal & Calcite & $\mathrm{KrS}$ & Kersutite & $\mathrm{Sp}$ & Spinel \\
\hline Cc & Chalcocite & $\mathrm{Kt}$ & Kataphorite & Sph & Sphalerite \\
\hline Cch & Clinochlore & Ky & Kyanite & Sps & Spessartine \\
\hline Cel & Celadonite & L & Liquid phase & Srp & Serpentine \\
\hline Chl & Chlorite & Le & Lepidolite & St & Staurolite \\
\hline Chm & Chamosite & Lex & Leucoxene & Stp & Stilpnomelane \\
\hline Chr & Chromite & $\mathrm{Lm}$ & Limonite & Str & Strontianite \\
\hline $\mathrm{Cmb}$ & Columbite & Lw & Lawsonite & Sym & Symplektite \\
\hline Cob & Cobaltite & $\mathrm{Ma}$ & Margarite & Tan & Tantalite \\
\hline Coe & Coesite & Mag & Magnesite & Tc & Talc \\
\hline Cor & Corundum & $\mathrm{Mb}$ & Molybdenite & Tht & Thorite \\
\hline $\mathrm{Cp}$ & Chalcopyrite & $\mathrm{Mi}$ & Microcline & Tmt & Titanomagnetite \\
\hline Cpx & Clinopyroxene & Mnt & Montmorillonite & To & Topaz \\
\hline Crb & Carbonate & Mnz & Monazite & $\operatorname{Tr}$ & Tremolite \\
\hline Crd & Cordierite & $\mathrm{Mr}$ & Marcasite & Ts & Tschermakite \\
\hline Crt & Carinthine & Mt & Magnetite & $\mathrm{Tt}$ & Titanite \\
\hline Cst & Cassiterite & $\mathrm{Mu}$ & Muscovite & $\mathrm{Tu}$ & Tourmaline \\
\hline Ctd & Chloritoid & $\mathrm{Ne}$ & Nepheline & Ur & Uraninite \\
\hline Cum & Cummingtonite & Oam & Orthoamphibole & Usp & Ulvospinel \\
\hline Czo & Clinozoisite & Ol & Olivine & Uvr & Uvarovite \\
\hline $\mathrm{Di}$ & Diopside & Om & Omphacite & Ver & Vermiculite \\
\hline Dol & Dolomite & Opq & Opaque minerals & Vs & Vesuvianite \\
\hline
\end{tabular}


End of Table 1

\begin{tabular}{l|l|l|l|l|l}
\hline Symbol & Full name & Symbol & Full name & Symbol & Full name \\
\hline Dph & Daphnite & Opx & Orthopyroxene & Wn & Winchite \\
\hline Ed & Edenite & Or & Orthoclase & Wo & Wollastonite \\
\hline En & Enstatite & Ort & Orthite & WR & Whole rock \\
\hline Ep & Epidote & Osm & Osumilite & Wt & Wolframite \\
\hline Fa & Fayalite & Pa & Paragonite & Xen & Xenotime \\
\hline fl & Fluid & Pe & Pentlandite & Ze & Zeolite \\
\hline Flu & Fluorite & Pg & Pargasite & Zo & Zoisite \\
\hline Fo & Forsterite & Pgt & Pigeonite & Zrn & Zircon \\
\hline
\end{tabular}

into consideration was garnet appearance or disappearance in paragenesis with plagioclase, cummingtonite, hornblende and clinopyroxene in metabasites. Estimation of pressure by this criterion is less certain but rather convenient because it is easy to identify the presence or absence of garnet in Ca-rich mafic rocks. At a moderate pressure and temperature parageneses with cummingtonite and plagioclase gradually disappear, and parageneses with garnet and hornblende appear as their alternative under relatively high pressures. As the pressure increases, cummingtonite and plagioclase are replaced by garnet with progressively increasing Mg content and by hornblende, which is progressively enriched in Al. The Cum+PI paragenesis thus becomes unstable in high-pressure complexes. Also, orthopyroxene is an important index mineral in mafic rocks at a high pressure and temperature. With increasing pressure, $\mathrm{Opx}+\mathrm{PI}$ becomes unstable, and this paragenesis is replaced by $\mathrm{Gr}+\mathrm{Cpx}+\mathrm{Pl}$ and eventually by $\mathrm{Gr}+\mathrm{Cpx}$.

Upon revising our earlier scheme [Bushmin, Glebovitsky, 2008], we decided not to distinguish the epidote-amphibolite facies as an independent one, and this facies is instead included in the lowtemperature part of amphibolite facies in our newly introduced variant of the scheme. Our reasoning is that the position of the high-T boundary of the epidote-amphibolite facies is very uncertain and depends on many factors. In particular, epidote and chlorite, typical of the epidote-amphibolite facies, can also remain stable in mafic rocks metamorphosed to the amphibolite facies (chlorite - in Mg-rich rocks, and epidote - in Ca-rich rocks). In this case, the characteristic paragenesis of the epidote-amphibolite facies in metabasites is $\mathrm{Hb}+\mathrm{Ep}+\mathrm{PI}+\mathrm{Chl}+\mathrm{Qu} \pm \mathrm{Gr}$, which can also be stable in the low-T part of the amphibolite facies. Only in the rocks of basaltic composition, the absence of epidote may indicate conditions of the amphibolites facies, when epidote eventually disappears at increasing temperature, and when the mineral paragenesis contains more amphibole and calcic plagioclase. Moreover, epidote contains $\mathrm{Fe}^{3+}$ and chlorite may also contain minor $\mathrm{Fe}^{3+}$, and their stability is thus very sensitive to the value of oxygen fugacity $\left(\mathrm{fO}_{2}\right)$. At increasing $\mathrm{fO}_{2}$ the field of epidote stability widens significantly towards higher temperatures. Also, in magnesium-rich metapelites, chlorite may remain stable up to the medium-T amphibolite facies. All these considerations made a ground to omit the epidote-amphibolite facies as an independent facies due to the significant uncertainties of its boundaries. Now we regard it as a low-temperature part of the amphibolite facies.

Analysis of experimental data and thermodynamic calculations shows that, on a generalized «universal P-T grid» for various rock types, the boundaries between mineral facies may be only gradual, due to the wide variation in the composition of mineral solid solutions, bulk rock chemistry, and water activity.

The proposed scheme of mineral facies demonstrates only the principal relationships between metamorphic facies and subfacies, with their boundaries often defined not by a single line but rather by a series of closely spaced lines of univariant reactions, in the result of which characteristic mineral parageneses appear or disappear. In a general case, these reactions relate to systems containing $\mathrm{K}, \mathrm{Na}, \mathrm{Ca}, \mathrm{Fe}, \mathrm{Mg}, \mathrm{Al}$, and $\mathrm{Si}$. The position of univariant boundary lines in P-T space depends on the composition of solid solutions in the MAS, FAS, FMAS, KFMAS, CFMAS and other systems. If other elements, e. g., Mn, Zn, Ti, and $\mathrm{Cr}$, are contained in a system, the stability fields of minerals that contain these elements expand, and the lines of the univariant reactions are accordingly transformed into divariant or multivariant fields. The boundaries become more diffuse and turn into linear tracts. Such effects of additional elements were considered in publications dedicated to this problem [e. g. Spear, 1993; Mahar et al., 1997; White et al., 2000; Tinkham et al., 2001; Ashley, Law, 2015]. Therefore, boundaries between adjacent facies and some subfacies in the scheme are shown not as thin lines but in the form of broad P-T transition zones (Fig. 1). It should be emphasized that the facies boundaries shown in Fig. 1 do 


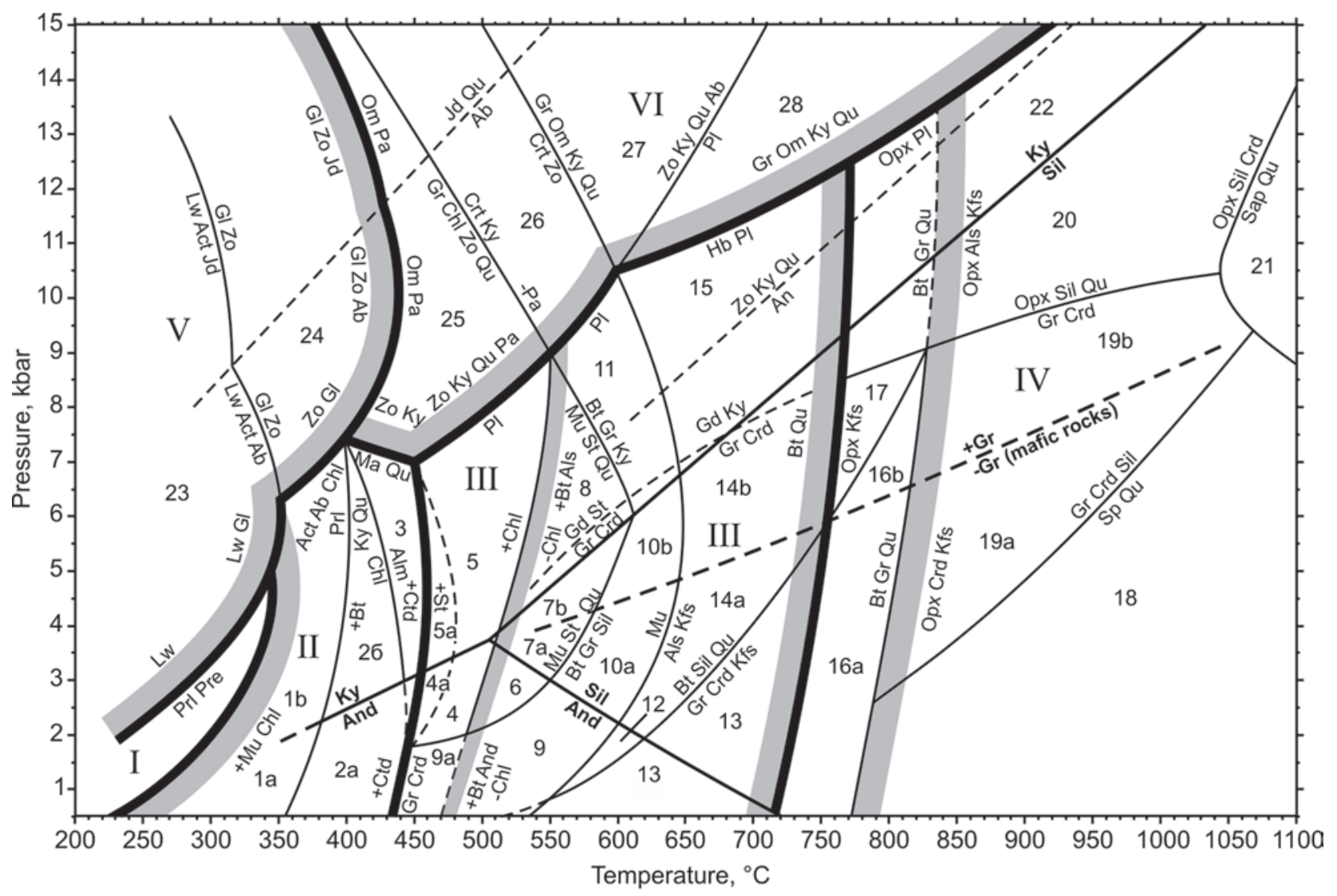

I Prehnite-pumpellyite facies

II Greenschist facies

1. Stilpnomelane-muscovite-chlorite

1 a - low-P (And-Sil type)

$1 \mathrm{~b}$ - high-P (Ky-Sil type)

2. Muscovite-chlorite-biotite

2a - low-P (And-Sil type)

$2 \mathrm{~b}$ - high-P (Ky-Sil type)

3. Chlorite-chloritoid-almandine

\section{Amphibolite facies}

4. Andalusite-chlorite-staurolite

4a - low-T zone (Ctd+St stable)

4 - Ctd out, St in

5. Kyanite-chlorite-staurolite

5a - low-T zone (Ctd+St stable)

5 - Ctd out, St in

6. Andalusite-biotite-staurolite

Chl out, Bt+And in

7. Sillimanite-biotite-staurolite

$\mathrm{Chl}$ out, Bt+Sil in

7 a - low-P (And-Sil type)

$7 \mathrm{~b}$ - high-P (Ky-Sil type)

8. Kyanite-biotite-staurolite

$\mathrm{Chl}$ out, Bt+Ky in

9. Andalusite-biotite-muscovite

St out, Bt+And in

$9 a$ - low-T zone (Ep, Chl stable)

9 - Ep, Chl out

10. Sillimanite-biotite-muscovite

St out

10a - low-P (And-Sil type)

10b - high-P (Ky-Sil type)

11. Kyanite-biotite-muscovite

St out

12. Biotite-andalusite-orthoclase

Mu out, Kfs+And in

13. Biotite-garnet-cordierite-orthoclase
14. Biotite-sillimanite-orthoclase

Mu out, Kfs+Sil in

$14 \mathrm{a}$ - low-P (And-Sil type)

$14 \mathrm{~b}$ - high-P (Ky-Sil type)

15. Biotite-kyanite-orthoclase

Mu out, Kfs+Ky in

IV Granulite facies

16. Biotite-garnet-orthoclase-orthopyroxene Opx+Kfs in

16a - low-P (And-Sil type)

$16 \mathrm{~b}$ - high-P (Ky-Sil type)

17. Biotite-garnet-sillimanite-orthoclase Opx+Kfs in

18. Quartz-spine/

$\mathrm{Opx}+\mathrm{Crd}+\mathrm{Kfs}$ in, $\mathrm{Sp}+\mathrm{Qu}$ in

19. Garnet-cordierite-orthoclase-orthopyroxene

$\mathrm{Opx}+\mathrm{Crd}+\mathrm{Kfs}$ in, $\mathrm{Gr}+\mathrm{Crd}$ in

$19 \mathrm{a}$ - low-P (And-Sil type)

$19 \mathrm{~b}$ - high-P (Ky-Sil type)

20. Sillimanite-orthopyroxene

Opx+Sil in

21. Quartz-sapphirine

Sap+Qu in

22. Kyanite-orthopyroxene

$\mathrm{Opx}+\mathrm{Ky}$ in

V Blueschist facies (high to ultrahigh-P)

23. Lawsonite-glaucophane

24. Zoisite-glaucophane

VI Eclogite facies (ultrahigh-P)

25. Paragonite-kyanite-zoisite

26. Zoisite-kyanite-carinthine

27. Garnet-kyanite-omphacite

28. Plagioclase-kyanite-omphacite

The line dividing facies and subfacies of Ky-Sil type

- $+\mathrm{Gr}-$ with a low T/P gradient and of And-Sil type with a high T/P gradient (garnet in/out in mafic rocks)

Fig. 1. Scheme of mineral facies of metamorphic rocks.

Facies - Roman numerals, subfacies - Arabic numerals 
not coincide exactly with the experimentally established reaction lines in simplified systems. The boundaries between facies or subfacies which deviate from experimentally validated boundary equilibria at $\mathrm{P}_{\mathrm{H} 2 \mathrm{O}}=\mathrm{P}_{\text {total }}$ are consistent with an appreciable decrease in $\mathrm{P}_{\mathrm{H} 2 \mathrm{O}}$ with depth. We assume [Glebovitsky, 1977; Korikovsky, 1979] that $\mathrm{P}_{\mathrm{H} 2 \mathrm{O}}=0.5-0.2 \mathrm{P}_{\text {total }}$ if the total pressure is higher than 5-6 kbar. These constraints determine the approximate position of curvilinear facies boundaries at variable $\mathrm{P}_{\mathrm{H} 2 \mathrm{O}}$ under high-temperature and high-pressure conditions. Vast information on the stability of mineral assemblages in real metamorphic complexes with estimated P-T parameters was also taken into account. Our newly obtained and published data [Korikovsky, 1979; Berman, 1991; Powell et al., 1998; Powell, Holland, 2008; Bushmin, Glebovitsky, 2008 and references therein] on particular mineral reactions (experiments, calculations, natural equilibria) make up the basis for the proposed scheme.

\section{Scheme of mineral facies of metamorphic rocks}

It is difficult to determine the boundary between diagenesis and metamorphism by petrographic criteria. Nevertheless, such a boundary could be established in the rocks according to the first appearance of zones or clusters with newly formed minerals being in physical-chemical equilibrium. Establishing equilibrium requires full recrystallization of the protolith minerals, for example, of clastic and clay fragments, the ordering of the structures of the mica-minerals and an equilibrium distribution of chemical components between the minerals.

Mineral parageneses are defined for various rock types (metapelites, metabasites, etc). We also use the terms «Ca-poor» and «Ca-rich» rocks, which have no genetic sense. The group of «Ca-poor» rocks comprises rock types in which $\mathrm{Ca}$ is contained mostly in plagioclase and, sometimes, in minor carbonates, and epidote (Al-metapelites, K-metapelites, K-poor metapelites, Mg-metapelites, K-metasandstones, metasandstones, metagranites, etc). The «Ca-rich» rocks group includes various rocks in which $\mathrm{Ca}$ is accommodated in rock-forming minerals (metamafic rocks or metabasites, for example, metabasalts, metaandesites, basic tuffs, basic metasandstones, some metagreywackes, metadiorites, metagabbros, etc). The mineral parageneses of calc-silicate rocks are described separately.

\subsection{Prehnite-pumpellyite (or zeolite) facies}

In this lowermost temperature facies of relatively low pressure (Fig. 1) the metamorphic recrystallization of whole rock is often feeble and mineral equilibria are often not reached on the whole-rock scale. In fact, this mineral assemblage consists of relic and newly formed metamorphic minerals. Rocks of this facies typically exhibit local alterations with equilibria often reached along fractures in the primary magmatic or sedimentary rocks. The facies is characterized by the presence of prehnite and pumpellyite in various parageneses with chlorite, zeolites (analcime, laumontite, stilbite, and wairakite), actinolite (at higher pressure and temperature), and albite in volcanic rocks and by the presence of kaolinite, hydromuscovite, montmorillonite, and vermiculite in metapelites.

\subsection{Greenschist facies}

In this low-temperature metamorphic facies (Fig. 1) muscovite, biotite and garnet first appear. Parageneses with chlorite and chloritoid become abundant in Ca-poor rocks. In Ca-rich rocks, assemblages of actinolite with epidote (or zoisite), albite and chlorite are stable. In calc-silicate rocks, the calcite+dolomite+quartz paragenesis is stable. Other minerals such as clinozoisite, chlorite, ankerite and scapolite may also be stable. At the low-temperature boundary of the greenschist facies, hydromicas, montmorillonite, and vermiculite disappear completely in metapelites, and chlorite+muscovite paragenesis appears. Kaolinite decomposes in Al-rich rocks and produces pyrophyllite. In metabasites the breakdown of prehnite and pumpellyite produces parageneses with actinolite, epidote, chlorite, albite, paragonite and carbonate. In this facies, the stilpnomelanemuscovite-chlorite (the first chlorite+muscovite), muscovite-chlorite-biotite (the first biotite) and chlorite-chloritoid-almandine (the first garnet) subfacies can be distinguished.

Stilpnomelane-muscovite-chlorite subfacies (1) (here and below, Arabic numerals of subfacies correspond to those in Fig. 1). In Ca-poor rocks quartz, chlorite, muscovite, albite, stilpnomelane, pyrophyllite, carbonates (ankerite and calcite), kaolinite, talc, paragonite, and occasional microcline are stable, whereas chloritoid, garnet, and biotite are unstable. In Ca-rich rocks quartz, albite, carbonates, chlorite, epidote, zoisite, actinolite are stable.

Muscovite-chlorite-biotite subfacies (2). Biotite is stable and widespread in K-metasandstones. Stilpnomelane gradually disappears in metapelites, and the first paragenesis with low-Al biotite appears: $\mathrm{Stp}+\mathrm{Chl}+\mathrm{Mu}=\mathrm{Bt}+\mathrm{Mu}$. The first high-Fe chloritoid as a product of the reaction $\mathrm{Chl}_{\mathrm{Fe}}+\mathrm{Prl}=\mathrm{Ctd}_{\mathrm{Fe}}+\mathrm{Qu}$ can appear at approximately the same temperature in high-Al metapelites. 
The first aluminum silicates (andalusite, kyanite) appear in high-Al metapelites as products of pyrophyllite dehydration. In Ca-poor rocks biotite, muscovite, phengite, chlorite, chloritoid, stilpnomelane, microcline, carbonates (ankerite and calcite), talc, albite and cummingtonite (in K-poor rocks) are stable. The assemblage of biotite with chloritoid is however unstable. In Ca-rich rocks quartz, albite, carbonates, epidote, clinozoisite, and chlorite are stable. Pale-colored hornblende may appear together with colorless actinolite, and pumpellyite disappears completely.

Chlorite-chloritoid-almandine subfacies (3) is typical of kyanite-type greenschist complexes. In andalusite-type complexes, this subfacies occurs only in a small high-temperature part of the greenschist facies. Under the conditions of this subfacies, the first Fe-rich garnet (almandine) appears as a product of Fe-chlorite breakdown in the reaction $\mathrm{Qu}+\mathrm{Chl}_{\mathrm{Fe}}=\mathrm{Gr}_{\mathrm{Fe}}$. With increasing temperature, the Mg-content of garnet and chlorite increases. As pressure increases, the reaction of chlorite decomposition shifts toward low temperatures (Fig. 1). Thus, at a higher pressure (more than $\sim 5$ kbar), the first garnet (almandine) gradually appears together with the first biotite. The paragenesis of almandine, chlorite and chloritoid is critical for this subfacies. Thus, chloritoid, kyanite (andalusite), chlorite, muscovite, almandine, albite, biotite, stilpnomelane, and cummingtonite (in $\mathrm{K}$-poor rocks) are stable in Ca-poor rocks. At the same time, assemblages biotite+andalusite (or kyanite) and biotite+chloritoid are unstable. In Ca-rich rocks colorless actinolite sometimes with pale-colored hornblende is stable, as well as chlorite, epidote, carbonates, albite, and garnet.

\subsection{Amphibolite facies}

The low-T boundary of amphibolite facies (Fig. 1) in metapelites at a pressure higher than 2 kbar is defined by the appearance of staurolite due to the gradual breakdown of chloritoid (transition to subfacies 4 and 5). Iron-richest chloritoid is the first to disappear. In the KFMAS system, the boundary is not a single line but a series of closely spaced lines of mineral reactions within a narrow $\mathrm{T}$ interval. As temperature increases in the field of andalusite stability, the reactions are: $\mathrm{Ctd}+\mathrm{Chl}+\mathrm{And}=\mathrm{St}+\mathrm{Qu}, \mathrm{Ctd}+\mathrm{And}+\mathrm{Qu}=\mathrm{St}+\mathrm{Gr}$, $\mathrm{Ctd}+\mathrm{Chl}+\mathrm{Qu}=\mathrm{St}+\mathrm{Gr}$, and $\mathrm{Ctd}+\mathrm{Qu}=\mathrm{St}+\mathrm{Chl}+\mathrm{Gr}$. In the field of kyanite stability the reactions are: $\mathrm{Ctd}+\mathrm{Chl}+\mathrm{Ky}=\mathrm{St}+\mathrm{Qu}, \mathrm{Ctd}+\mathrm{Chl}+\mathrm{Mu}=\mathrm{St}+\mathrm{Bt}+\mathrm{Qu}$, $\mathrm{Ctd}+\mathrm{Ky}+\mathrm{Qu}=\mathrm{St}+\mathrm{Gr}, \mathrm{Ctd}+\mathrm{Mu}+\mathrm{Qu}=\mathrm{St}+\mathrm{Bt}+\mathrm{Gr}$, and $\mathrm{Ctd}+\mathrm{Qu}=\mathrm{St}+\mathrm{Gr}+\mathrm{Ky}$. In a very narrow temperature interval (within the Ky field) the biotite+chloritoid paragenesis can be stable:
$\mathrm{Gr}+\mathrm{Chl}+\mathrm{Mu}=\mathrm{Bt}+\mathrm{Ctd}+\mathrm{Qu}$. In Mg-metapelites, mainly in the field of andalusite stability, the first cordierite may appear as a product of the reaction $\mathrm{Phl}+\mathrm{Als}=\mathrm{Crd}_{\mathrm{Mg}}+\mathrm{Mu}$. At pressures lower than 2 kbar, where staurolite is completely unstable, the low-T boundary with the greenschist facies is defined by a series of closely spaced reaction lines in the narrow temperature transition zone 9a: $\mathrm{Ctd}+\mathrm{Qu}=\mathrm{Gr}+\mathrm{Crd}+\mathrm{Chl}, \mathrm{Ctd}+\mathrm{Qu}=\mathrm{Chl}+\mathrm{Gr}+\mathrm{And}$, $\mathrm{And}+\mathrm{Chl}+\mathrm{Qu}=\mathrm{Gr}+\mathrm{Crd}$, and $\mathrm{Chl}+\mathrm{Mu}+\mathrm{Qu}=\mathrm{Bt}+\mathrm{Crd}$. As a consequence, chloritoid disappears, chlorite disappears gradually, and parageneses of cordierite with garnet and biotite with andalusite appear in subfacies 9: Chl+Mu+Qu $=\mathrm{Gr}+\mathrm{Crd}+\mathrm{Bt}$ and $\mathrm{Gr}+\mathrm{Chl}+\mathrm{Mu}=\mathrm{Bt}+\mathrm{And}+\mathrm{Qu}$.

In metabasites, actinolite disappears, and the parageneses of bluish green hornblende with epidote, plagioclase (oligoclase), chlorite and garnet are stable. Garnet is however less typical, and even completely absent at a low pressure if the rocks are not rich in Fe. Increasing pressure widens the field of epidote (clinozoisite, zoisite)+plagioclase stability towards high temperatures (subfacies 5).

The wide temperature range of this facies (from $\sim 450$ to $\sim 750{ }^{\circ} \mathrm{C}$ ) enables the subdivision of the amphibolite facies into low-, medium- and high$T$ parts. The abundance of various metapelitic assemblages sensitive to variation in P-T conditions makes it possible to distinguish a series of temperature subfacies at different pressures.

The low-T part of the amphibolite facies (subfacies 5,4 ) is the stability field of staurolite-bearing mineral assemblages together with chlorite in metapelites. The parageneses chlorite+staurolite \pm garnet and chlorite+cordierite are widespread. At a very low pressure (zone 9a of subfacies 9), the paragenesis garnet+cordierite without staurolite appears for the first time among chlorite assemblages. Parageneses of bluish green and green hornblende with epidote, chlorite, plagioclase (albite-oligoclase), and garnet (Ferich rocks) are stable in metabasites. These rocks are characterized by an abundance of equilibrium chlorite. In calc-silicate rocks the dolomite+quartz paragenesis may be preserved or alternative tremolite+calcite paragenesis appears. Other minerals such as hornblende, chlorite, clinozoisite, zoisite, ankerite, scapolite, and garnet (grossularandradite) may also be stable.

Subfacies 4 and 5 correspond to different pressure conditions. The andalusite-chlorite-staurolite subfacies (4) is characterized by the stability of muscovite, biotite, andalusite, staurolite, cordierite, garnet, anthophyllite (in K-poor rocks), and chlorite. The kyanite-chlorite-staurolite subfacies (5) is characterized by the stability of muscovite, staurolite, biotite, kyanite, garnet, chlorite, and 
cordierite (only at moderate $\mathrm{P}$ near the andalusite field). Cummingtonite is stable in $\mathrm{K}$-poor rocks in both subfacies. There is a narrow temperature zone $\left(\sim 450-480^{\circ} \mathrm{C}\right)$ in subfacies 4 and 5 in which the parageneses chloritoid+staurolite and chloritoid+biotite are stable in high-Al metapelites up to the complete decomposition of chloritoid (transition zones $4 a$ and $5 a$ ). The assemblage cordierite+staurolite is unstable within the entire temperature interval of subfacies 4 and 5.

The medium-T part of the amphibolite facies (Fig. 1) in metapelites encompasses the stability field of staurolite-bearing assemblages (subfacies $6,7,8)$, after chlorite disappearence in the rocks with a medium $\mathrm{Mg}$ content, and the stability field of two-mica with alumina silicates assemblages (subfacies 9, 10, 11) after complete disappearance of staurolite and the «last» chlorite (in Mgrich rocks). In subfacies 6, 7, 8 the assemblage of staurolite with cordierite and without chlorite develops for the first time, but it is abundant only in low-P metapelites of andalusite-sillimanite complexes (subfacies 6, 7a). For the first time, the parageneses of biotite+aluminum silicates (kyanite or andalusite or sillimanite) appear at moderate to high pressures in staurolite-bearing rocks and at low pressures (less than 2 kbar) in staurolite-free biotite-garnet schists. In Ca-rich rocks epidote and chlorite disappear from the hornblende assemblages, except for the situations discussed above. In calc-silicate rocks clinopyroxene (diopside) first appears after the breakdown of dolomite+quartz and tremolite+calcite+quartz assemblages. As a result, diopside or alternative tremolite+calcite+quartz paragenesis may be stable. At higher temperature in quartz-free rocks clinopyroxene together with calcite and tremolite are stable. Other minerals such as hornblende, clinozoisite, zoisite, scapolite, and garnet (grossular-andradite) may also be stable. Also, it is noteworthy that at low pressures (subfacies 9, 6) the medium-T part of the amphibolite facies begins at a temperature around $480-500{ }^{\circ} \mathrm{C}$, whereas at high pressures (subfacies 8 ) it begins at $\sim 550^{\circ} \mathrm{C}$.

The transition to the medium-T part of the amphibolite facies (to subfacies $6,7,8$ and 9, 10, 11) in metapelites is defined by the disappearance of chlorite-bearing assemblages in the staurolite stability field and by the first appearance of biotite in parageneses with aluminum silicates (andalusite, sillimanite, and kyanite). This transition is via a series of closely spaced lines of mineral reactions. In the field of kyanite stability these reactions are: $\mathrm{St}+\mathrm{Chl}+\mathrm{Mu}=\mathrm{Bt}+\mathrm{Ky}+\mathrm{Qu}$, $\mathrm{Gr}+\mathrm{Chl}+\mathrm{Mu}=\mathrm{Bt}+\mathrm{Ky}+\mathrm{Qu}, \mathrm{St}+\mathrm{Chl}+\mathrm{Qu}=\mathrm{Gr}+\mathrm{Crd}$ (narrow P-T space), $\mathrm{Ky}+\mathrm{Chl}+\mathrm{Qu}=\mathrm{St}+\mathrm{Crd}$, $\mathrm{Chl}+\mathrm{Mu}+\mathrm{Qu}=\mathrm{Bt}+\mathrm{Crd}, \mathrm{Chl}+\mathrm{Mu}+\mathrm{Qu}=\mathrm{Bt}+\mathrm{Crd}+\mathrm{Ky}(\mathrm{at}$ moderate pressure), and $\mathrm{Chl}+\mathrm{Mu}=\mathrm{Bt}+\mathrm{Ky}+\mathrm{Qu}$. In the field of andalusite stability these reactions are: $\mathrm{St}+\mathrm{Chl}+\mathrm{Mu}=\mathrm{Bt}+\mathrm{And}+\mathrm{Qu}, \mathrm{St}+\mathrm{Chl}+\mathrm{Qu}=\mathrm{Gr}+\mathrm{Crd}$, $\mathrm{And}+\mathrm{Chl}+\mathrm{Qu}=\mathrm{St}+\mathrm{Crd}, \mathrm{Chl}+\mathrm{Mu}+\mathrm{Qu}=\mathrm{Bt}+\mathrm{Crd}$, and $\mathrm{Chl}+\mathrm{Mu}+\mathrm{Qu}=\mathrm{Bt}+\mathrm{Crd}+\mathrm{And}$. Outside the staurolite stability field at pressures less than 2 kbar, after chlorite disappearance in the transition zone 9a, the paragenesis of biotite and andalusite appears also in subfacies 9: $\mathrm{Gr}+\mathrm{Chl}+\mathrm{Mu}=\mathrm{Bt}+\mathrm{And}+\mathrm{Qu}$. But in Mg-metapelites, Mg-chlorite with muscovite, biotite and andalusite can still be stable.

Depending on pressure, the staurolite stability field without chlorite can be subdivided into the andalusite-biotite-staurolite (6), sillimanite-biotite-staurolite (7), and kyanite-biotite-staurolite (8) subfacies. These staurolite-bearing subfacies in metapelites are characterized by the stability of staurolite, muscovite, biotite, kyanite (sillimanite, andalusite), garnet, cummingtonite (K-poor rocks), gedrite (K-poor rocks in kyanite field), anthophyllite (K-poor rocks in andalusite field), and cordierite. At the same time, the assemblage biotite+garnet+kyanite (sillimanite, andalusite) is unstable in all these subfacies. Cordierite is abundant mainly in the field of andalusite and sillimanite stability (subfacies 6 and 7). Cordierite together with garnet is unstable in kyanite field (subfacies 8). However, this assemblage is stable under a lower pressure together with sillimanite (subfacies 7) or andalusite (subfacies 6). Bluish green hornblende, plagioclase, garnet, clinopyroxene, cummingtonite, and in certain situations also epidote, zoisite, chlorite (subfacies 6), and carbonates are stable in Ca-rich rocks.

Depending on pressure, two-mica with alumina silicates parageneses can be subdivided into the andalusite-biotite-muscovite (9), sillimanite-biotite-muscovite (10), and kyanite-biotite-muscovite (11) subfacies. The boundary between subfacies $6,7,8$ and subfacies 9, 10, 11 is identified by the disappearance of staurolite and Mg-chlorite: St+Mu+Qu = Bt+Gr+Ky (Sil, And), $\mathrm{St}+\mathrm{Qu}=\mathrm{Gr}+\mathrm{Gd}+\mathrm{Ky}, \mathrm{St}+\mathrm{Qu}=\mathrm{Gr}+\mathrm{Crd}+\mathrm{Sil}$, $\mathrm{St}+\mathrm{Qu}=\mathrm{Gr}+\mathrm{Crd}+\mathrm{And}$, and $\mathrm{Chl}_{\mathrm{Mg}}+\mathrm{Mu}=\mathrm{Phl}+$ Als. Around this boundary, the univariant $\mathrm{Bt}+\mathrm{Als}+\mathrm{Gr}+\mathrm{St}+\mathrm{Mu}+\mathrm{Qu}$ paragenesis can exist and is commonly found in metapelites. In K-metapelites (muscovite-bearing schists) staurolite disappears at a temperature (maximum $\sim 600-620^{\circ} \mathrm{C}$ ) lower than that in $\mathrm{K}$-poor metapelites (maximum $\sim 650^{\circ} \mathrm{C}$ ), in which, for example, an alternative paragenesis of gedrite, kyanite and garnet is formed at a high pressure. Subfacies 9, 10, 11 in Ca-poor rocks are characterized by the stability of andalusite (sillimanite, kyanite), biotite, muscovite, garnet, cordierite, cummingtonite (K-poor rocks), plagioclase, and gedrite ( $\mathrm{K}$-poor rocks in the field of 
andalusite and sillimanite). Cordierite is stable and abundant mainly in the field of andalusite and sillimanite (subfacies 9 and 10), whereas in the field of kyanite (subfacies 11) this mineral can be stable in Al-, Mg-metapelites. Cordierite together with garnet are not stable in the field of kyanite (subfacies 11), and at a lower pressure, they are stable with sillimanite (subfacies 10) and andalusite (subfacies 9). In the low-temperature part of the lowpressure andalusite-biotite-muscovite subfacies (9), chlorite can be preserved in Mg-metapelites. In K-poor rocks containing gedrite and cummingtonite, Fe-orthopyroxene appears for the first time as a product of the reactions $\mathrm{Cum}+\mathrm{Gr}=\mathrm{Gd}+\mathrm{Opx}$, $\mathrm{Gr}+\mathrm{Gd}=\mathrm{Opx}+\mathrm{Qu}$, and $\mathrm{Cum}+\mathrm{Mt}=\mathrm{Opx}+\mathrm{Qu}$.

The medium-T subfacies of the amphibolite facies in metabasites are defined by the disappearance of epidote and chlorite from hornblende-plagioclase (oligoclase-andesine) assemblages and appearance of the $\mathrm{Hb} \pm \mathrm{Cpx}+\mathrm{Gr}+\mathrm{PI}$ paragenesis of the high-P amphibolite facies in the kyanite-syllimanite type of metamorphism (subfacies $7 \mathrm{~b}, 10 \mathrm{~b}$, $14 b, 8,11,15)$, and the $\mathrm{Hb} \pm \mathrm{Cpx}+\mathrm{Cum}+\mathrm{PI}$ paragenesis of low-P amphibolite facies in the andalusitesillimanite type of metamorphism (subfacies 7a, 10a, 14a, 6, 9, 12). As pressure decreases, garnet and aluminous hornblende disappear gradually from the assemblages of these subfacies. At first, parageneses with low-Al hornblende, cummingtonite, garnet and plagioclase appear. Then low-P parageneses without garnet begin to form. Occasionally, in the medium-T part of the amphibolite facies, $\mathrm{Mg}$-chlorite remains in parageneses with hornblende. The disappearance or existence of epidote containing $\mathrm{Fe}^{3+}$ depends on $\mathrm{fO}_{2}$.

The high-temperature part of the amphibolite facies, in which anataxis and migmatization of rocks start to develop, is the P-T stability field of orthoclase-bearing assemblages with biotite and aluminum silicates as products of muscovite breakdown before the appearance of orthopyroxene in metapelites (subfacies 12, 13, 14, 15). Zones with rocks bearing the sillimanite+orthoclase paragenesis are sometimes called second sillimanite zones. In metabasites, hornblende parageneses with plagioclase and clinopyroxene are widespread. Depending on pressure and Fe content, cummingtonite and garnet appear in or disappear from these parageneses. In calc-silicate rocks the assemblage $\mathrm{Cal}+\mathrm{Tr}$ disappears and parageneses with clinopyroxene become abundant. Hornblende, plagioclase and calcite are stable. At higher temperature forsterite becomes stable. Other minerals such as scapolite, garnet (grossular-andradite), and dolomite may also be stable.
Depending on pressure, this part of the amphibolite facies is subdivided into the biotite-andalusite-orthoclase (12), biotite-garnet-cordierite-orthoclase (13), biotite-sillimanite-orthoclase (14), and biotite-kyanite-orthoclase (15) subfacies. The boundary between «muscovite» $(9,10$, 11) and "orthoclase» $(12,13,14,15)$ subfacies is identified by the complete disappearance of muscovite. In Ca-rich rocks epidote, zoisite, and chlorite disappear completely; and brown-green hornblende, plagioclase, garnet, clinopyroxene and cummingtonite are stable. In K-poor rocks, cummingtonite, anthophylite (commonly in the field of andalusite) and gedrite (in the field of sillimanite and kyanite) as well as Fe-orthopyroxene can occur. The biotite-andalusite-orthoclase subfacies (12) occupies a small field, in which the biotite+andalusite+orthoclase paragenesis may contain cordierite and garnet. However, garnet, cordierite and orthoclase are unstable if occurring together. The biotite-sillimanite-orthoclase subfacies (14) occupies an extensive field, in which the biotite-sillimanite-orthoclase paragenesis may also contain cordierite and garnet, but the $\mathrm{Gr}+\mathrm{Crd}+\mathrm{Kfs}$ assemblage is unstable here similar to subfacies 12 . The boundary of the biotitegarnet-cordierite-orthoclase subfacies (13) with subfacies 12 and 14 is determined by the disappearance of the $\mathrm{Bt}+\mathrm{Sil}$ (And)+Qu paragenesis. Under the conditions of subfacies 13, biotite, garnet, cordierite, sillimanite (andalusite) and orthoclase are stable in various combinations, except only for $\mathrm{Bt}+\mathrm{Als}+\mathrm{Qu}$. Around this boundary the univariant $\mathrm{Bt}+\mathrm{Sil}+\mathrm{Gr}+\mathrm{Crd}+\mathrm{Kfs}$ paragenesis can exist. Biotite, kyanite, garnet and orthoclase are stable under the conditions of the biotite-kyanite-orthoclase subfacies 15 . In this subfacies cordierite is of limited abundance in Mg-rich metapelites and the garnet+cordierite assemblage is unstable.

\subsection{Granulite facies}

In general, this is a P-T stability field for the orthopyroxene-orthoclase paragenesis in Ca-poor rocks and orthopyroxene-clinopyroxene-plagioclase paragenesis with garnet (at higher pressure) or without garnet (at lower pressure) in Ca-rich rocks (Fig. 1). The low-T boundary of granulite facies in Ca-poor rocks is defined by the gradual appearance of the orthopyroxene+orthoclase paragenesis as a breakdown product of low-Al and low- Mg biotite by the reaction $\mathrm{Bt}+\mathrm{Qu}=\mathrm{Kfs}+\mathrm{Opx}$ and/or by dehydration melting. The further transition at increasing temperature to orthoclasecordierite-orthopyroxene granulite is related to the gradual decomposition of high-Al and relatively low-Mg biotite: $\mathrm{Bt}+\mathrm{Gr}+\mathrm{Qu}=\mathrm{Kfs}+\mathrm{Crd}+\mathrm{Opx}$. 
In Mg-rich rocks, however, biotite is preserved. Ca-free amphibole disappears completely. Under the same T-conditions, hornblende and cummingtonite disappear from mineral assemblages in Carich rocks. At higher pressure, the $\mathrm{Cpx} \pm \mathrm{Opx}+\mathrm{Gr}+\mathrm{PI}$ paragenesis of high-P granulite facies (subfacies $16 b, 17,19 b, 20,21,22$ ) appears due to intensive growth of garnet at increasing pressure. But at lower pressure, the garnet-free $\mathrm{Cpx} \pm \mathrm{Opx}+\mathrm{PI}$ paragenesis of moderate- and low- $\mathrm{P}$ granulite facies (subfacies 16a, 19a, 18) is stable. Hornblende breakdown depends on water activity, quartz content in the rock and on its $\mathrm{Mg}$ content. That is why hornblende often occurs in granulites. In calc-silicate rocks clinopyroxene, calcite, forsterite, plagioclase, hornblende, garnet (grossular-andradite), and wollastonite may be stable. Wollastonite can appear in these rocks as a result of the reaction $\mathrm{Cal}+\mathrm{Qu}=$ Wo.

The granulite facies is subdivided into the biotite-garnet-orthoclase-orthopyroxene (16), biotite-garnet-sillimanite-orthoclase (17), quartzspinel (18), garnet-cordierite-orthoclase-orthopyroxene (19), sillimanite-orthopyroxene (20), quartz-sapphirine (21), and kyanite-orthopyroxene (22) subfacies.

The biotite-garnet-orthoclase-orthopyroxene (16) and biotite-garnet-sillimanite-orthoclase (17) subfacies are the transitional low-T part of the granulite facies at low and moderate pressures, where the breakdown of biotite in Ca-poor rocks initiates the formation of the stable assemblage of orthopyroxene and orthoclase, but still without cordierite, which will appear in this paragenesis at a higher temperature. Orthopyroxene, high-Al and high-Ti biotite, sillimanite, garnet, cordierite, and orthoclase are stable under the conditions of these subfacies. However, Opx+Sil, Opx+Crd+Kfs, and $\mathrm{Gr}+\mathrm{Crd}+\mathrm{Kfs}$ assemblages are unstable in subfacies 17, and the Opx+Sil and Opx+Crd+Kfs assemblages are unstable in subfacies 16. Around the boundary between subfacies 16 and 17 the univariant $\mathrm{Bt}+\mathrm{Sil}+\mathrm{Gr}+\mathrm{Crd}+\mathrm{Kfs}$ paragenesis is possible for several reasons, including the expansion of the garnet stability field due to variation in the $\mathrm{Ca}$ and Mn contents and the expansion of the biotite stability field due to variation in $\mathrm{Fe}, \mathrm{Al}$ and $\mathrm{Ti}$. In Ca-rich rocks, garnet in paragenesis with pyroxenes and brown hornblende is common only in subfacies 17 and 16b, whereas in subfacies 16a garnet disappears completely at pressures decreasing from moderate to low.

The quartz-spinel (18) and garnet-cordieriteorthoclase-orthopyroxene (19) subfacies occupy the high-temperature part of the granulite facies at low and moderate pressures. These high-T granulites are characterized by the disappearance of sillimanite and garnet assemblages with low-Mg high-Al biotite and the appearance of the orthopyroxene+orthoclase+cordierite paragenesis. Orthopyroxene, garnet, cordierite, sillimanite, orthoclase, and spinel (with quartz only in subfacies 18) are stable under the conditions of subfacies 18 and 19, but the Opx+Sil+Qu assemblage is unstable, and the $\mathrm{Gr}+\mathrm{Crd}+\mathrm{Sil}$ assemblage is stable only in subfacies 19 . It should be noted that $\mathrm{Zn}$-bearing spinel, which is not rare in granulites, can also be stable with quartz at much higher pressures and lower temperatures than in subfacies 18. Mg-rich biotite may occur in K-metapelites together with orthoclase and orthopyroxene up to $\sim 850-900^{\circ} \mathrm{C}$ and then it disappears gradually by the reactions $\mathrm{Bt}_{\mathrm{FeMg}}+\mathrm{Qu}=\mathrm{Bt}_{\mathrm{Mg}}+\mathrm{Opx}+\mathrm{Crd}+\mathrm{Kfs}$ and $\mathrm{Bt}_{\mathrm{Mg}}+\mathrm{Qu}=\mathrm{Opx}_{\mathrm{Mg}}+\mathrm{Crd}_{\mathrm{Mg}}+\mathrm{Kfs}$. In Ca-rich rocks, garnet in association with pyroxenes and brown hornblende is typical only of the high-P part (subfacies $19 b)$ of the garnet-cordierite-orthoclase-orthopyroxene subfacies (19). When pressure drops, garnet disappears from the parageneses with pyroxenes and hornblende (subfacies 19a) and is as a rule absent in Ca-rich parageneses of the quartz-spinel subfacies (18).

The sillimanite-orthopyroxene (20), quartzsapphirine (21) and kyanite-orthopyroxene (22) subfacies occupy the high-T and high-P (more than $\sim 9$ kbar) part of the granulite facies. The low-P boundary of the sillimanite-orthopyroxene subfacies (20) is defined by the disappearance of the $\mathrm{Gr}+\mathrm{Crd}$ assemblage and the appearance of the alternative $\mathrm{Opx}+\mathrm{Sil}+\mathrm{Qu}$ paragenesis. The high-P boundary of the sillimanite-orthopyroxene subfacies (20) with kyanite-orthopyroxene subfaces (22) is defined by the appearance of the $\mathrm{Ky}+\mathrm{Opx}$ paragenesis at the phase transition of sillimanite into kyanite and, as a result, the breakdown of the most magnesian «last» cordierite: $\mathrm{Crd}_{\mathrm{Mg}}=\mathrm{Opx}_{\mathrm{Mg}}+\mathrm{Ky}+\mathrm{Qu}$.

In the low-T part of the sillimanite-orthopyroxene (20) and kyanite-orthopyroxene (22) subfacies near the boundary with the amphibolite facies, the stable mineral assemblage consists of orthopyroxene, sillimanite (kyanite), quartz and garnet, but without orthoclase. Orthoclase appears in this paragenesis at increasing temperature as a product of the reaction $\mathrm{Bt}+\mathrm{Gr}+\mathrm{Qu}=\mathrm{Opx}+\mathrm{Als}+\mathrm{Kfs}$. Under the conditions of subfacies 20 and 22, biotite, orthopyroxene, garnet, sillimanite (kyanite), cordierite (only in subfacies 20), sapphirine, orthoclase, and spinel are stable in Ca-poor rocks, but the assemblages sapphirine+quartz, spinel+quartz, and cordierite+garnet are unstable. As in the low-pressure granulite subfacies, the preservation of biotite depends on the contents of $\mathrm{Mg}, \mathrm{Al}, \mathrm{Ti}$, and water 
activity, so that the $\mathrm{Bt}+\mathrm{Opx}+\mathrm{Sil}+\mathrm{Kfs}+\mathrm{Qu}$ paragenesis is preserved in, for example, Mg-metapelites. In Ca-rich rocks, the stable mineral assemblage consists of pyroxenes, brown hornblende (only in the low-T region), garnet, and plagioclase.

The Qu+Sap paragenesis is the main criterion for recognition of the quartz-sapphirine subfacies (21). Its boundary with the sillimanite-orthopyroxene subfacies (20) is determined by the reaction $\mathrm{Opx}+\mathrm{Sil}+\mathrm{Crd}=\mathrm{Sap}+\mathrm{Qu}$; the boundary with the garnet-cordierite-orthoclase-orthopyroxene subfacies (19) by the reaction $\mathrm{Crd}+\mathrm{Gr}+\mathrm{Sil}=\mathrm{Sap}+\mathrm{Qu}$; and the boundary with the quartz-spinel subfacies (18) by the reaction $\mathrm{Sp}+\mathrm{Crd}+\mathrm{Sil}=\mathrm{Sap}+\mathrm{Qu}$. Under the conditions of the quartz-sapphirine subfacies (21), the following minerals are stable in various combinations: sapphirine, biotite, orthopyroxene and sillimanite (sillimanite together with orthopyroxene only in the restricted high-pressure part of this subfacies), garnet and cordierite (only in the low-temperature part near the boundary with subfacies 19), orthoclase and spinel (spinel together with quartz only in the restricted part of relatively low pressure).

\subsection{Blueschist (or glaucophane-schist) facies}

The blueschist facies (Fig. 1) is a temperature analogue of the prehnite-pumpellyite and greenschist facies at high- and ultrahigh-P. The parageneses of glaucophane, lawsonite, muscovite, phengite and pumpellyite with such typical greenschist minerals as actinolite, zoisite, pyrophylite, chlorite, garnet, paragonite, stilpnomelane, albite, epidote, calcite, and quartz are stable in Ca-rich rocks. At pressures higher than $\sim 8-11$ kbar, almost pure jadeite may appear in paragenesis with quartz. The lawsonite-glaucophane subfacies (23) corresponds to the lowest temperature conditions such as in prehnite-pumlellyite and the low greenschist facies, but at high-P (up to 12-13 kbar). The zoisiteglaucophane subfacies (24) at temperatures of the prehnite-pumlellyite and greenschist facies corresponds to even higher pressures, up to 13-15 kbar.

The boundary of the lawsonite-glaucophane subfacies (23) with the prehnite-pumpellyite facies and partly with the greenschist facies is determined by the reactions $\mathrm{Pr}+\mathrm{Prl}=\mathrm{Lw}+\mathrm{Qu}, \mathrm{Pr}+\mathrm{Cal}=\mathrm{Lw}+\mathrm{Zo}$ and $\mathrm{Chl}+\mathrm{Ab}=\mathrm{Gl}, \mathrm{Act}+\mathrm{Chl}+\mathrm{Ab}+\mathrm{Qu}=\mathrm{Lw}+\mathrm{Gl}$. As a result, the parageneses of lawsonite and glaucophane with chlorite and albite, with calcite and albite, or with calcite and chlorite, which are typical of this subfacies, appear.

The boundary of the zoisite-glaucophane subfacies (24) with the greenschist facies is determined by the reactions $\mathrm{Act}+\mathrm{Chl}+\mathrm{Ab}=\mathrm{Gl}+\mathrm{Zo}+\mathrm{Qu}$ and $\mathrm{Act}+\mathrm{Chl}+\mathrm{Pa}+\mathrm{Ab}=\mathrm{Zo}+\mathrm{Gl}$. Consequently, parageneses of zoisite or epidote and glaucophane with actinolite and albite, with chlorite and albite, and with chlorite and actinolite become common.

The boundary between subfacies 23 and 24 is established by the appearance of zoisite (epidote)+glaucophane paragenesis and gradual disappearance of lawsonite: $\mathrm{Lw}+\mathrm{Act}+\mathrm{Ab}=\mathrm{Zo}+\mathrm{Gl}$ and $\mathrm{Lw}+\mathrm{Act}+\mathrm{Jd}=\mathrm{Zo}+\mathrm{Gl}$ (these reactions are assumed as a boundary), Lw+Qu = Zo+Prl. At increasing temperature, the paragenesis of glaucophane and paragonite appears by the reaction $\mathrm{ChI}_{\mathrm{Al}}+\mathrm{Ab}=\mathrm{Gl}+\mathrm{Pa}$. Also, transitional parageneses of zoisite and glaucophane with chlorite and pargasite, pargasite and omphacite, or omphacite and albite can appear near the high-temperature boundary with the eclogite facies (subfacies 25). It is worth noting however that the boundary of lawsonite disappearance at increasing $\mathrm{T}$ and $\mathrm{P}$ depends considerably on $\mathrm{H}_{2} \mathrm{O}$ activity. In a scenario with a high value of this parameter $\left(\mathrm{P}_{\mathrm{H} 2 \mathrm{O}} \sim \mathrm{P}_{\text {total }}\right)$, lawsonite remains stable together with glaucophane till the high-T boundary with plagioclase-free zoisitekyanite-quartz eclogites (subfacies 25), in which it breaks down via the reaction $\mathrm{Lw}=\mathrm{Zo}+\mathrm{Ky}+\mathrm{Qu}$. In this case the fields of the lawsonite-glaucophane subfacies (23) and zoisite-glaucophane subfacies (24) overlap and the paragenesis of zoisite, kyanite and quartz may appear in the field of glaucophane stability. The appearance of omphacite in blueschists in the transitional zone to plagioclasefree eclogites (subfacies 25) is explained in the same way.

\subsection{Eclogite facies}

The eclogite facies (Fig. 1) is a temperature analogue of the amphibolite and granulite facies at ultrahigh pressures. The widespread paragenesis of omphacite with garnet (typically pyrope and grossular-rich) is characteristic of this facies. The paragenesis of almost pure jadeite with quartz is formed at pressures higher than $\sim 12$ kbar. Other minerals such as amphibole (pargasite), epidote, zoisite, kyanite, paragonite, albite, and $\mathrm{Na}-\mathrm{Ca}$-plagioclase may also be stable in the eclogite facies. Often rutile occurs there. Parageneses and various mineral reactions in eclogites after different protolith in the transition zone from amphibolite and granulite facies are well documented in many publications [e. g. Korikovsky et al., 1997, 1998a, b, 2004; Korikovsky, 2005, 2009, 2012; Kozlovskii et al., 2015].

Eclogite rocks of the paragonite-kyanite-zoisite (25), zoisite-kyanite-carinthine (26) and garnet-kyanite-omphacite (27) subfacies with the zoizite+kyanite+quartz paragenesis are sometimes called plagioclase-free eclogites and the rocks of 


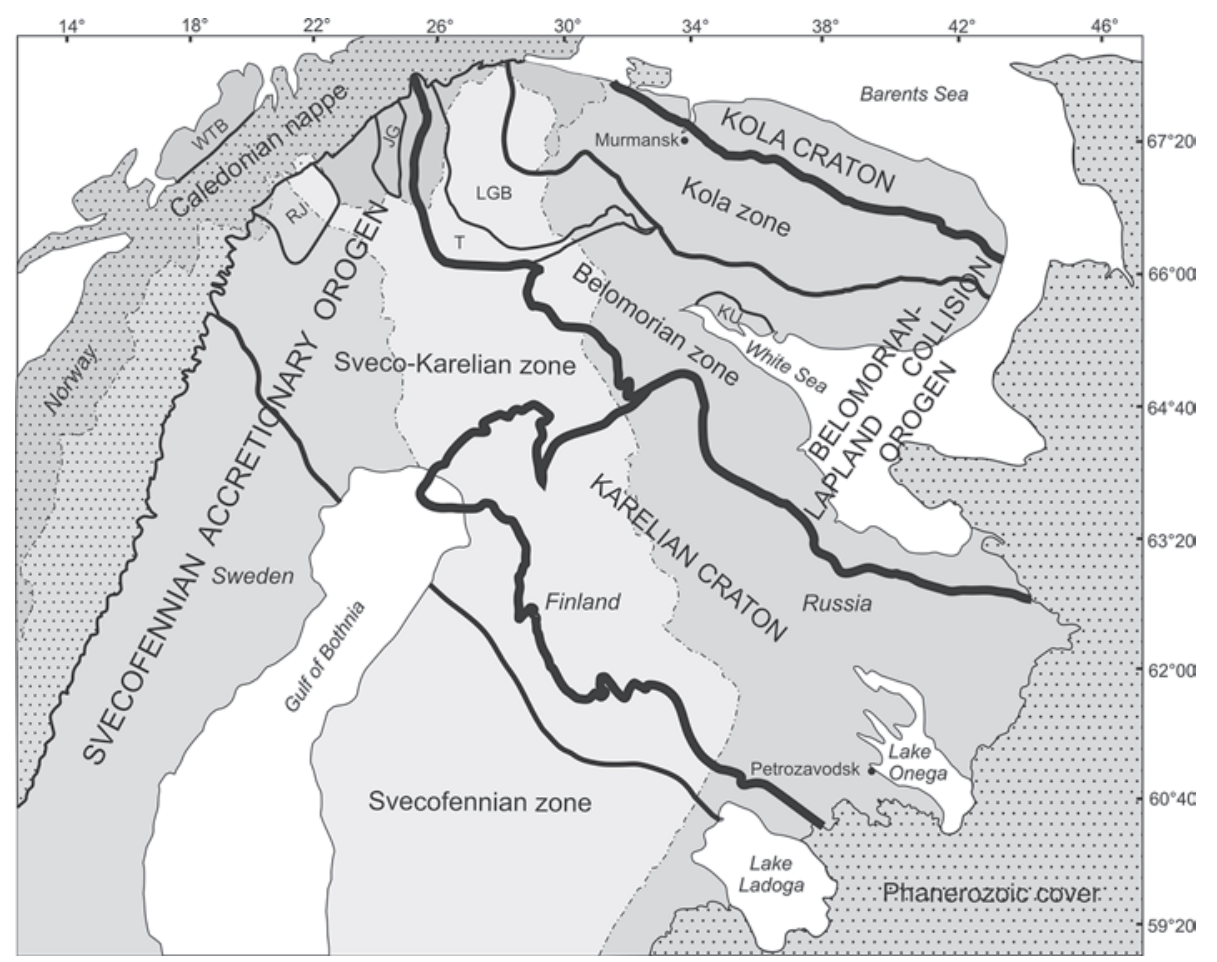

Fig. 2. Major tectonic units of the Fennoscandian Shield.

LGB - Lapland Granulite belt, T - Tana belt

Archean enclaves of the Karelian craton (Archean crust) occurring as relicts within the Sveco-Karelian tectonic zone of the Svecofennian orogen: WTB - West Troms Basement Complex, RJ - Råstojaure complex, JG - Jergul complex

the plagioclase-kyanite-omphacite subfacies (28) are called plagioclase eclogites.

The low-temperature boundary of the eclogite facies with the blueschist facies is rather uncertain, because the eclogite mineral assemblage can occur in the high-temperature part of the blueschist facies with glaucophane-bearing assemblages. Glaucophane gradually disappears as a result of mineral transformations, e. g. by the reactions $\mathrm{Zo}+\mathrm{Gl}+\mathrm{Ab}=\mathrm{Om}+\mathrm{Pa}, \mathrm{Zo}+\mathrm{Gl}+\mathrm{Jd}=\mathrm{Om}+\mathrm{Pa}$, $\mathrm{Gl}+\mathrm{Zo}=\mathrm{Pg}+\mathrm{Pa}$, and $\mathrm{Gl}+\mathrm{Pg}+\mathrm{Qu}=\mathrm{Om}+\mathrm{Gr}$.

The paragonite-kyanite-zoisite (25) and zoisite-kyanite-carinthine (26) eclogite subfacies correspond to the temperature conditions of the low- to medium-T amphibolite facies. In subfacies 25 parageneses with paragonite, zoisite, kyanite, quartz, omphacite, pargasite, chlorite, and garnet are widespread, but the assemblages pargasite+kyanite, omphacite+kyanite, and omphacite+kyanite+garnet are unstable. The lowpressure boundary with the low amphibolite facies is determined in Ca-rich rocks by the appearance of zoisite in paragenesis with kyanite, quartz, and paragonite as products of margarite and plagioclase decomposition: $\mathrm{Ma}+\mathrm{Qu}=\mathrm{Zo}+\mathrm{Ky}$ and $\mathrm{PI}_{\mathrm{CaNa}}=\mathrm{Zo}+\mathrm{Ky}+\mathrm{Qu}+\mathrm{Pa}$.

In the zoisite-kyanite-carinthine subfacies (26) at increasing temperature paragonite becomes unstable as a result of the reaction
$\mathrm{Pa}+\mathrm{Qu}=\mathrm{Ab}+\mathrm{Ky}$, and the carinthine+kyanite paragenesis becomes stable as a result of the reaction $\mathrm{Gr}+\mathrm{Chl}+\mathrm{Zo}+\mathrm{Qu}=\mathrm{Crt}+\mathrm{Ky}$. Parageneses with carinthine (brown pargasite with high $\mathrm{Mg}, \mathrm{Ca}, \mathrm{Al}$, Ti contents, typical of eclogites), kyanite, zoisite, omphacite, quartz, albite, and garnet are typical of this subfacies. The low-P boundary, as in subfacies 25, is determined by the reaction of plagioclase breakdown: $\mathrm{PI}_{\mathrm{CaNa}}=\mathrm{Zo}+\mathrm{Ky}+\mathrm{Qu}+\mathrm{Ab}$. The boundary between the zoizite-kyanite-carinthine subfacies (26) and subfacies 25 is determined by the decomposition of chlorite-zoisite schists with the formation of the parageneses with carinthine and kyanite: $\mathrm{Gr}+\mathrm{Chl}+\mathrm{Zo}+\mathrm{Qu}=\mathrm{Crt}+\mathrm{Ky}$. Talc in paragenesis with kyanite and muscovite \pm paragonite (so-called whiteschists) can appear in subfacies 25 and 26 at the boundary with the amphibolite facies in Mg-metapelites as a product of the reactions $\mathrm{ChI}_{\mathrm{Mg}}+\mathrm{Phl}=\mathrm{Tc}+\mathrm{Mu}, \mathrm{ChI}_{\mathrm{Mg}}=\mathrm{Tc}+\mathrm{Ky}$, and $\mathrm{Ab}+\mathrm{Ky}=\mathrm{Pa}+\mathrm{Qu}$.

The garnet-kyanite-omphacite eclogite subfacies (27) corresponds to the temperature conditions of medium-T amphibolite facies. Subfacies 27 includes parageneses of omphacite and garnet with kyanite, zoisite, and quartz, which are products of the breakdown of carinthine in assemblage with zoisite at the boundary with the zoisitekyanite-carinthine subfacies (26) via the reaction $\mathrm{Crt}+\mathrm{Zo}=\mathrm{Om}+\mathrm{Gr}+\mathrm{Ky}+\mathrm{Qu}$. 


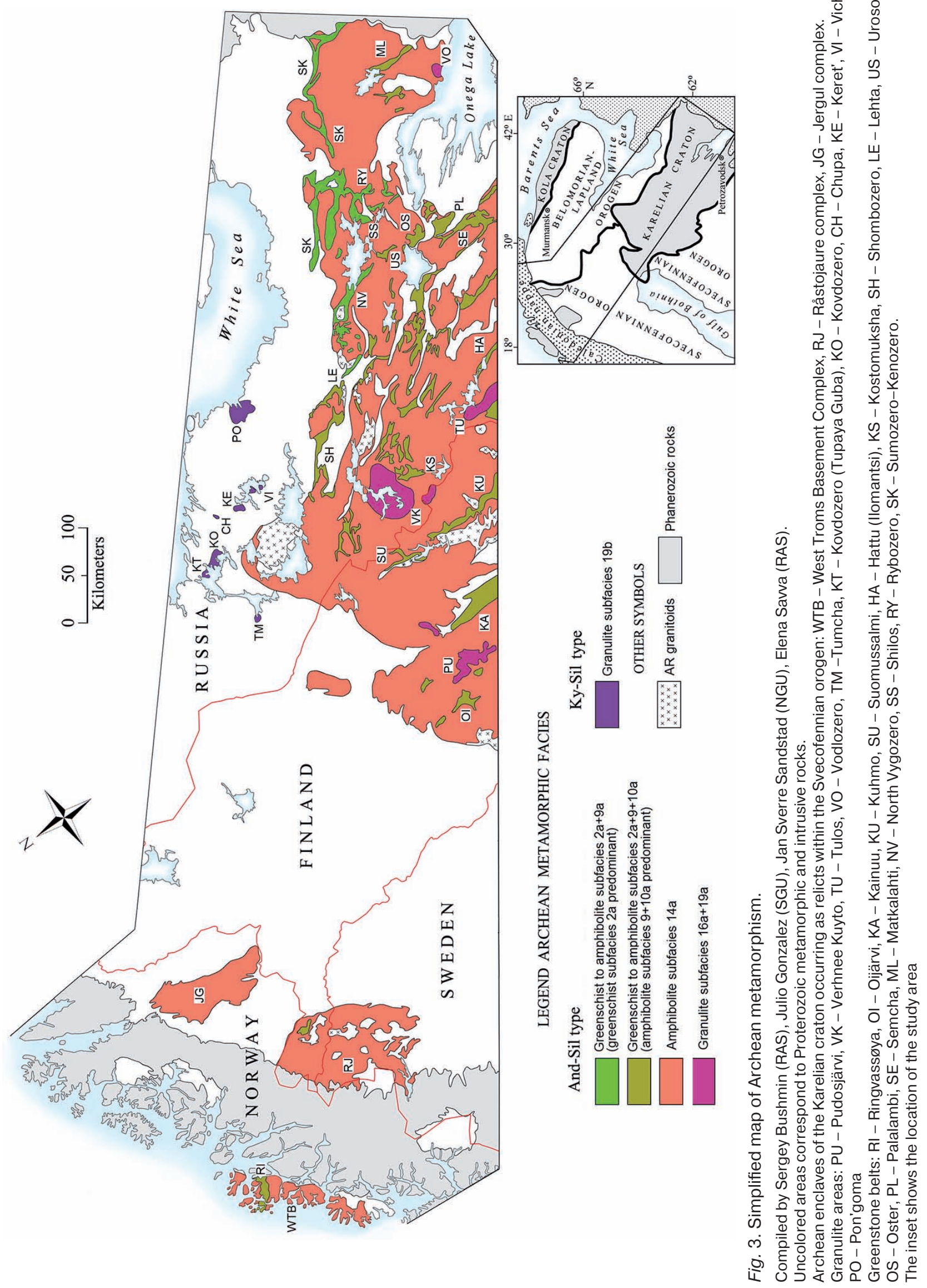




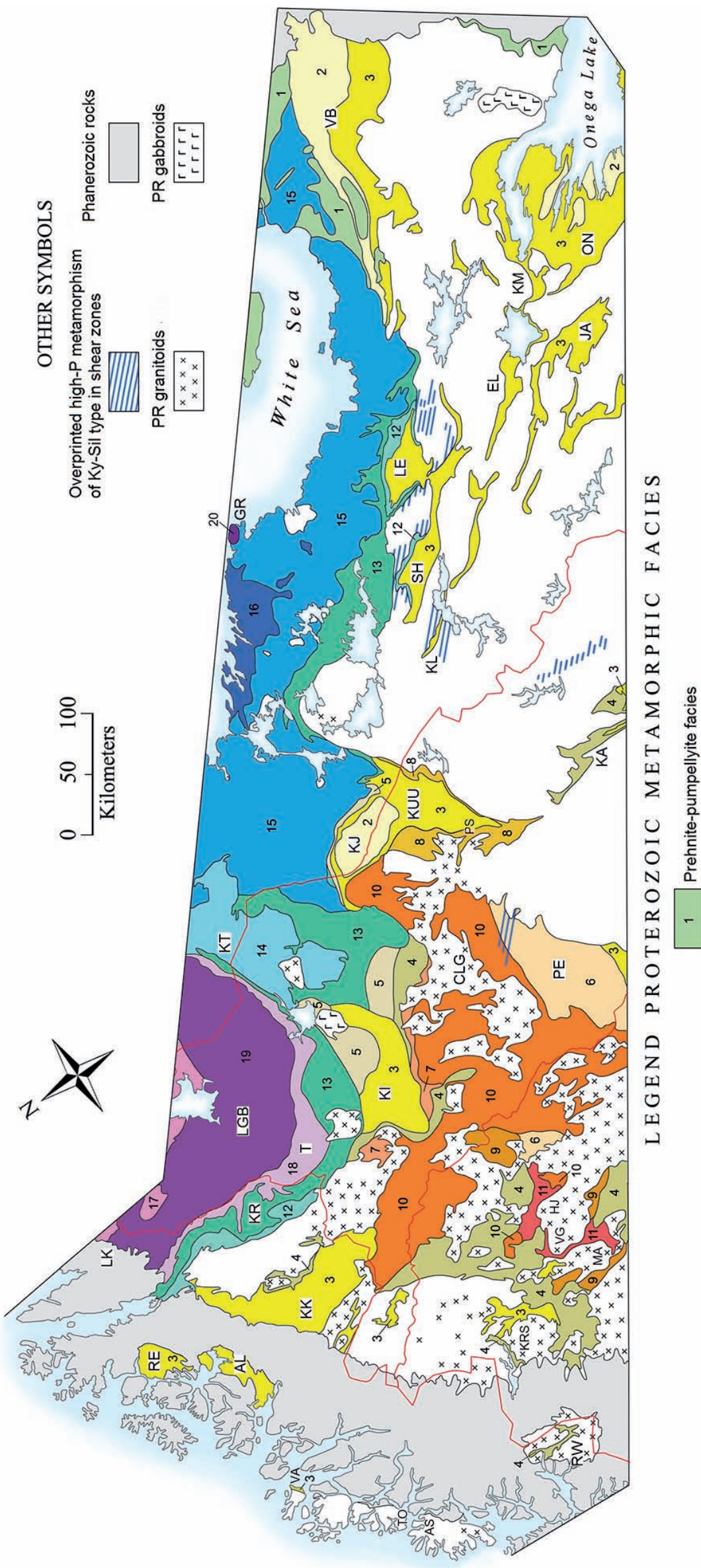

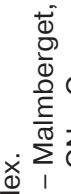

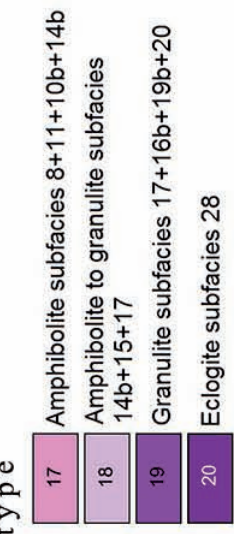

हों $\sum \sum \frac{\pi}{0}$

응 흥는

क्षे

는

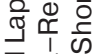

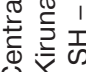

1 1

نㄴ.

高

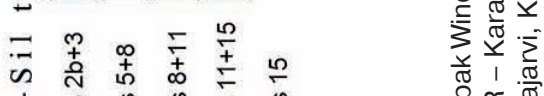

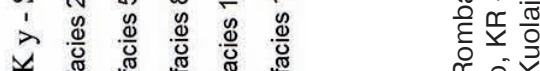

व

类旁文

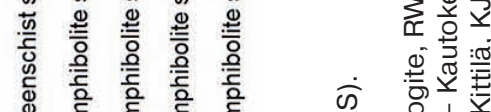

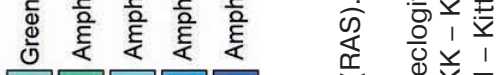

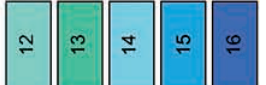

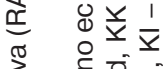

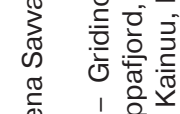

它

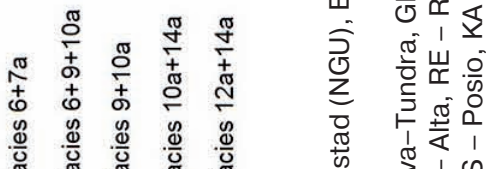

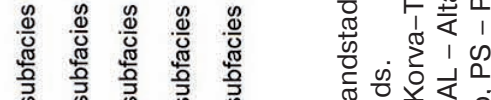

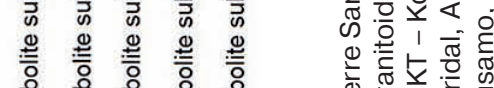

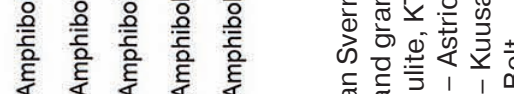

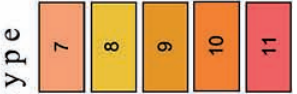

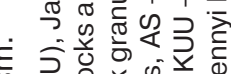

类

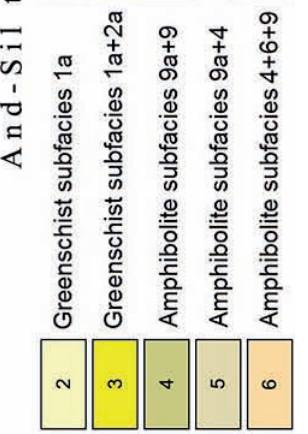

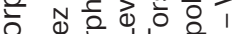

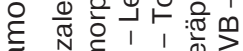

శٓ

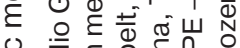

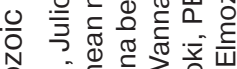

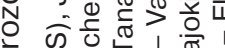

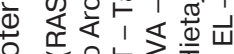

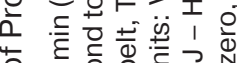

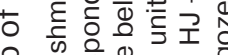

बे

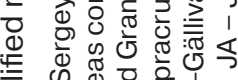

है ठิ

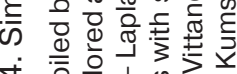

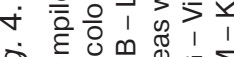

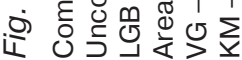




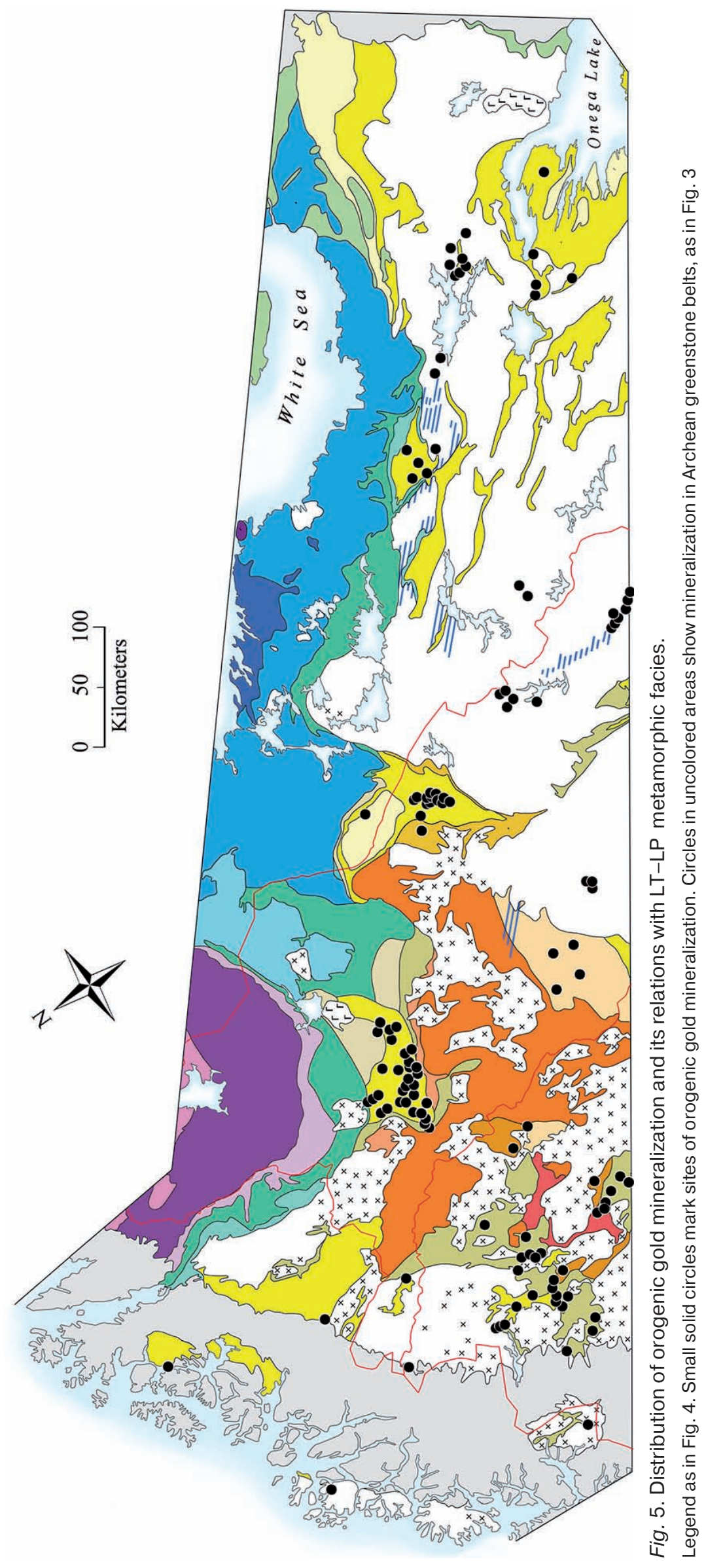


The plagioclase-kyanite-omphacite eclogite subfacies (28) corresponds to the temperature conditions of the high-amphibolite and granulite facies. The low-T boundary of subfacies 28 with subfacies 27 is defined by the disappearance of the zoisite+kyanite+quartz assemblage and appearance of plagioclase in eclogite as a product of the reaction $\mathrm{ZO}+\mathrm{Ky}+\mathrm{Qu}+\mathrm{Ab}=\mathrm{Pl}_{\mathrm{CaNa}}$.

The low-P boundary of the plagioclasekyanite-omphacite subfacies (28) with amphibolite and granulite facies is well specified in Ca-rich rocks by the appearance of the omphacite+kyanite+garnet paragenesis due to the reaction of plagioclase with hornblende or orthopyroxene: $\mathrm{Hb}+\mathrm{PI}=\mathrm{Om}+\mathrm{Gr}+\mathrm{Ky}+\mathrm{Qu}$ and $\mathrm{Opx}+\mathrm{PI}=\mathrm{Gr}+\mathrm{Om}+\mathrm{Ky}+\mathrm{Qu}$. Eclogite-like clinopyroxene-plagioclase-garnet rocks are also widespread in this transitional zone. In metapelites at the low-P boundary, the kyanite+orthoclase paragenesis of the amphibolite and granulite facies remains stable under eclogite facies conditions, but the granulite orthopyroxene+kyanite paragenesis disappears: $\mathrm{Opx}_{\mathrm{Mg}}+\mathrm{Ky}=\mathrm{Gr}_{\mathrm{Mg}}+\mathrm{Qu}$. In K-poor Mg-metapelites, talc can appear in the paragenesis with kyanite as a product of the reactions $\mathrm{Crd}_{\mathrm{Mg}}=\mathrm{Ta}+\mathrm{Ky}+\mathrm{Qu}$ (subfacies 27 and 28 at the boundary with the amphibolite facies) and $\mathrm{Opx}_{\mathrm{Mg}}+\mathrm{Qu}=\mathrm{Ta}+\mathrm{Ky}$ (subfacies 28 at the boundary with the granulite facies).

\section{Conditions, setting, and evolution of metamorphism}

Typical parageneses of metamorphic facies/ subfacies (Fig. 1) formed after various protolith and characterized above are listed in Table 2. The attention is focused on metamorphic facies belonging to the andalusite-sillimanite and kyanite-sillimanite facies series which predominate in the Fennoscandian Shield. The metamorphic conditions are presented with regard to their spatial relations with the major tectonic units of the Fennoscandian Shield (Fig. 2). The maps (Fig. 3, 4) show the prevailing $P-T$ conditions of regional metamorphism of Archean and Proterozoic age. The small scale of Figures 3 and 4 allows us to display only groups of undivided subfacies. Because of this, the maps do not show small relicts of older metamorphism. The color code is used for metamorphic facies series of andalusite-sillimanite and kyanite-sillimanite types as reflecting high and low thermal T/P gradients [Miyashiro, 1961; Hietanen, 1967; Glebovitsky, 1971, 1973; Brown, 2007, 2014]. Intrusive rocks that are either weakly metamorphosed or not metamorphosed at all, and preserve their primary magmatic textures and mineral composition are left colorless. The maps do not show younger overprinting metamorphism related to shear zones of Svecofennian age, because it is not possible to portray it on this scale. Nevertheless, the map of Proterozoic metamorphism (Fig. 4) does show certain areas in Finland and Russia with overprinting metamorphism as zones with colored stripes superimposed on a background color (or uncolored) areas corresponding to regional metamorphism. These high-P and low- to medium-T (rarely high-T) shear zones are widespread over the territory of the Karelian craton and were locally found in the Svecofennian orogen. These shear zones are characterized by high-P metamorphism of the KySil type (parageneses with kyanite in metapelites and with garnet in metabasites). Also, the maps do not show late retrograde metamorphism related to the exhumation of the metamorphic complexes (assemblages with late andalusite, sillimanite-fibrolite, etc.) and various metasomatic processes in shear zones.

In constructing the maps we made use of data presented in the Map of mineral facies of metamorphic rocks in the Eastern Baltic Shield [Belyaev et al., 1991], Map of metamorphism and transpression tectonics of the Precambrian of Karelia [Volodichev, 2002], and in the Geological map of the Fennoscandian Shield [Koistinen et al., 2001]. For the territory of Norway we also used data published in [Gaal et al., 1978; Barbey et al., 1980; Bernard-Griffiths et al., 1984; Krill, 1985; Marker, 1988, 1991; Marker et al., 1990; Bergh et al., 2010]. For Sweden data were taken from [Idman, 1988; Sawyer, Korneliussen, 1989; Bergman et al., 2001; Käpyaho et al., 2007; Bushmin et al., 2013]. Data on Finland were compiled from [Eskola, 1952; Korsman et al., 1984, 1999; Perttunen et al., 1996; Pajunen, Poutiainen, 1999; Hölttä et al., 2000, 2007, 2012; Hölttä, Paavola, 2000; Laajoki, 2000; Evins, Laajoki, 2001; Räsänen, Vaasjoki, 2001; Mänttäri, Hölttä, 2002; Tuisku et al., 2006; Tuisku, Huhma, 2006; Käpyaho et al., 2007; Kontinen et al., 2007; Kivisaari, 2008; Bushmin et al., 2013]. For the territory of Russia data were published in [Shemyakina, 1983; Baikova et al., 1984; Chekulaev, Baikova, 1984; Lobach-Zhuchenko et al., 1986, 1993, 2000; Belyaev et al., 1990, 1991; Volodichev, 1990, 1994, 1997, 2002; Daly, Bogdanova, 1991; Bibikova et al., 1993, 1995, 1999, 2001a, 2001b, 2004; Frisch et al., 1995; Miller et al., 1995; Astafiev, 1996; Glebovitsky, 1996, 1997, 2005; Glebovitsky et al., 1996, 2000; Sedova et al., 1996; Gerya, 1999; Perchuk et al., 1999, 2000; Miller, 2002; Volodichev et al., 2002, 2004, 2011; Balagansky et al., 2005; Balagansky, Glebovitsky, 2005; Bushmin et al., 2007, 2009, 2013; Mints et al., 2007; Kuleshevich, Lavrov, 2011; Skublov et al., 2011; Lebedeva et al., 2012; Myskova et al., 2012]. 
Table 2. Typical mineral parageneses of subfacies in various types of metamorphic rocks

\begin{tabular}{|c|c|c|}
\hline Rock type & Paragenesis & Comment \\
\hline \multicolumn{3}{|c|}{ Greenschist facies } \\
\hline \multicolumn{3}{|c|}{$\begin{array}{c}\text { Stilpnomelane-muscovite-chlorite subfacies } \mathbf{( 1 )} \\
\text { (subfacies - } 1 \text { a in And-Sil complexes and subfacies - } 1 \text { b in Ky-Sil complexes) }\end{array}$} \\
\hline Al-metapelites & $\mathrm{Qu}+\mathrm{Prl}+\mathrm{Mu}+\mathrm{Chl}$ & \\
\hline K-metapelites & $\mathrm{Qu}+\mathrm{Chl}+\mathrm{Mu} \pm \mathrm{Ab}$ & \\
\hline K-poor metapelites & $\begin{array}{l}\text { Qu+Prl+Chl } \\
\text { Qu+Stp+Chl } \pm T c\end{array}$ & FeMg-Tc \\
\hline K-metasandstones & $\mathrm{Qu}+\mathrm{Ab}+\mathrm{Chl}+\mathrm{Mu} \pm \operatorname{Stp} \pm \mathrm{Kfs}$ & \\
\hline Metasandstones & $\mathrm{Qu}+\mathrm{Ab}+\mathrm{Chl}+\mathrm{Mu} \pm \mathrm{Ep} \pm(\mathrm{Ank}, \mathrm{Cal})$ & \\
\hline Metabasites & Qu+Ab+Chl+Ep+Act $\pm($ Ank, Cal) & \\
\hline
\end{tabular}

Muscovite-chlorite-biotite subfacies (2)

(subfacies 2a in And-Sil complexes and subfacies $2 b$ in Ky-Sil complexes)

\begin{tabular}{|c|c|c|}
\hline Al-metapelites & $\mathrm{Qu}+\mathrm{Ctd}+\mathrm{Ky}(\mathrm{And})+\mathrm{Mu}+\mathrm{Chl} \pm \mathrm{Prl}$ & Fe-Ctd \\
\hline K-metapelites & $\mathrm{Qu}+\mathrm{Chl}+\mathrm{Mu} \pm \mathrm{Ab} \pm \mathrm{Bt}$ & $\mathrm{Chl}_{0-100}$ \\
\hline K-poor metapelites & $\begin{array}{l}\text { Qu+Ctd }+ \text { Chl } \pm \text { Ky(And) } \\
\text { Qu+Stp }+C h l \pm C u m \pm T c\end{array}$ & Fe-Cum, FeMg-Tc \\
\hline K-metasandstones & $\mathrm{Qu}+\mathrm{Ab}+\mathrm{Bt}+\mathrm{Chl}+\mathrm{Mu} \pm \mathrm{Kfs}$ & \\
\hline Metasandstones & $\mathrm{Qu}+\mathrm{Ab}+\mathrm{Chl}+\mathrm{Mu}+\mathrm{Bt} \pm(\mathrm{Ank}, \mathrm{Cal}) \pm \mathrm{Ep}$ & $\mathrm{Chl}_{0-100}$ \\
\hline Metabasites & $\mathrm{Qu}+\mathrm{Ab}+\mathrm{Act}+\mathrm{Chl}+\mathrm{Ep} \pm($ Ank,Cal $)$ & \\
\hline Calc-silicates & $\mathrm{Cal}+\mathrm{Dol}+\mathrm{Qu} \pm \mathrm{Ank} \pm \mathrm{Chl} \pm \mathrm{CzO} \pm \mathrm{Scp}$ & \\
\hline \multicolumn{3}{|c|}{ Chlorite-chloritoid-almandine subfacies (3) } \\
\hline Al-metapelites & $\begin{array}{l}\mathrm{Qu}+\mathrm{Ctd}+\mathrm{Ky}(\mathrm{And})+\mathrm{Chl}+\mathrm{Mu} \\
\mathrm{Qu}+\mathrm{Gr}+\mathrm{Ctd}+\mathrm{Chl}+\mathrm{Mu}\end{array}$ & $\begin{array}{l}\mathrm{Chl}_{25-100} \\
\mathrm{Gr}_{0-10}\end{array}$ \\
\hline K-metapelites & $\mathrm{Qu}+\mathrm{Gr}+\mathrm{Chl}+\mathrm{Mu} \pm \mathrm{Ab}(\mathrm{Pl}) \pm \mathrm{Bt}$ & $\mathrm{Chl}_{25-100}, \mathrm{Gr}_{0-10}$ \\
\hline K-poor metapelites & $\begin{array}{l}\mathrm{Qu}+\mathrm{Ctd}+\mathrm{Chl} \pm \mathrm{Gr} \pm \mathrm{Ky} \\
\mathrm{Qu}+\mathrm{Cum}+\mathrm{Chl} \pm \mathrm{Gr} \pm \text { Stp }\end{array}$ & \\
\hline K-metasandstones & $\mathrm{Qu}+\mathrm{Bt}+\mathrm{Mu} \pm \mathrm{Mi}+\mathrm{Ab}(\mathrm{PI})$ & \\
\hline Metasandstones & $\mathrm{Qu}+\mathrm{Bt} \pm \mathrm{Gr}+\mathrm{Chl}+\mathrm{Mu} \pm \mathrm{Ep}+\mathrm{Ab}(\mathrm{PI})$ & $\mathrm{Gr}_{0-10}, \mathrm{ChI}_{25-100}$ \\
\hline Metabasites & $\mathrm{Qu}+\mathrm{Ab}(\mathrm{Pl})+\mathrm{Act}+\mathrm{Chl}+\mathrm{Ep} \pm \mathrm{Gr} \pm($ Ank, Cal $)$ & Al-Act, $\mathrm{Chl}_{25-100}$ \\
\hline Calc-silicates & Cal+Dol+Qu \pm Ank $\pm C h l \pm C z o \pm S c p$ & \\
\hline \multicolumn{3}{|c|}{ Amphibolite facies } \\
\hline \multicolumn{3}{|c|}{ Chlorite-chloritoid-staurolite zones $4 a$ and $5 a$ in low-T part of subfacies (4) and (5) } \\
\hline Al-metapelites & $\begin{array}{l}\mathrm{Qu}+\mathrm{St}+\mathrm{Ctd} \pm \mathrm{Chl}+\mathrm{Ky}(\mathrm{And})+\mathrm{Mu} \\
\mathrm{Qu}+\mathrm{Ctd}+\mathrm{Gr}+\mathrm{Chl} \pm \mathrm{Bt}+\mathrm{Mu}\end{array}$ & $\mathrm{Gr}_{0-15}, \mathrm{Chl}_{40-100}$ \\
\hline K-metapelites & $\mathrm{Qu}+\mathrm{Gr}+\mathrm{Bt}+\mathrm{Chl}+\mathrm{Mu} \pm \mathrm{Pl}$ & $\mathrm{Gr}_{0-15}, \mathrm{Chl}_{40-100}$ \\
\hline Mg-metapelites & Qu+Bt+Crd+Chl+Mu (And-Sil complexes) & Mg-Bt, Mg-Crd \\
\hline K-poor metapelites & $\begin{array}{l}\text { Qu+St+Ctd } \pm G r \pm K y(\text { And }) \\
\text { Qu+Cum+Chl } \pm \mathrm{Gr}\end{array}$ & \\
\hline K-metasandstones & $\mathrm{Qu}+\mathrm{PI}+\mathrm{Bt}+\mathrm{Mu} \pm \mathrm{Kfs} \pm \mathrm{Gr}$ & \\
\hline Metasandstones & $\mathrm{Qu}+\mathrm{Pl}+\mathrm{Bt}+\mathrm{Gr}+\mathrm{Chl}+\mathrm{Mu} \pm \mathrm{Ep}$ & $\mathrm{Gr}_{0-15}, \mathrm{Chl}_{40-100}$ \\
\hline Metabasites & $\mathrm{Qu}+\mathrm{Pl}+\mathrm{Hb}+\mathrm{Chl}+\mathrm{Ep} \pm \mathrm{Ank}, \mathrm{Cal} \pm \mathrm{Gr}$ & $\mathrm{Hb}$ blue-green, $\mathrm{Chl}_{40-100}$ \\
\hline Calc-silicates & $\mathrm{Cal}+\mathrm{Dol}+\mathrm{Qu} \pm \mathrm{Hb} \pm \mathrm{Ank} \pm \mathrm{Chl} \pm \mathrm{Czo}(\mathrm{Zo}) \pm \mathrm{Scp} \pm(\mathrm{Grs}-\mathrm{Adr})$ & $\mathrm{Hb}$ colorless \\
\hline \multicolumn{3}{|c|}{ Andalusite-chlorite-staurolite (4) and kyanite-chlorite-staurolite (5) subfacies } \\
\hline Al-metapelites & $\mathrm{Qu}+\mathrm{St}+\mathrm{Chl}+\mathrm{Ky}(\mathrm{And})+\mathrm{Gr}+\mathrm{Mu}$ & $\mathrm{Chl}_{50-100}$ \\
\hline K-metapelites & $\mathrm{Qu}+\mathrm{Bt}+\mathrm{Gr}+\mathrm{St}+\mathrm{Chl}+\mathrm{Mu}$ & $\mathrm{Gr}_{0-20}, \mathrm{Chl}_{50-100}$ \\
\hline Mg-metapelites & $\mathrm{Qu}+\mathrm{Bt}+\mathrm{Crd}+\mathrm{Chl}+\mathrm{Mu}$ (And-Sil complexes) & $\mathrm{Mg}-\mathrm{Bt} \mathrm{Mg}-\mathrm{Crd}$ \\
\hline K-poor metapelites & $\begin{array}{l}\mathrm{Qu}+\mathrm{St}+\mathrm{Gr}+\mathrm{Ky}(\mathrm{And}) \pm \mathrm{Chl} \\
\mathrm{Qu}+\mathrm{Cum} \pm \mathrm{Chl} \pm \mathrm{Ant}+\mathrm{Gr}\end{array}$ & \\
\hline K-metasandstones & $\mathrm{Qu}+\mathrm{PI}+\mathrm{Bt}+\mathrm{Mu} \pm \mathrm{Kfs} \pm \mathrm{Gr}$ & \\
\hline Metasandstones & $\mathrm{Qu}+\mathrm{Pl}+\mathrm{Bt} \pm \mathrm{Gr} \pm \mathrm{Chl}+\mathrm{Mu} \pm \mathrm{Ep}$ & $\mathrm{Gr}_{0-20}, \mathrm{Chl}_{55-100}$ \\
\hline \multirow[t]{2}{*}{ Metabasites } & $\mathrm{Qu}+\mathrm{Pl}+\mathrm{Hb}+\mathrm{Gr} \pm \mathrm{Czo}(\mathrm{Zo})(\mathrm{Ky}-$ Sil complexes) & \multirow{2}{*}{$\begin{array}{l}\mathrm{Hb} \text { blue-green, } \\
\mathrm{Chl}_{50-100}, \mathrm{Gr}_{0-20}\end{array}$} \\
\hline & $\mathrm{Qu}+\mathrm{Pl}+\mathrm{Hb} \pm \mathrm{Cum}+\mathrm{Chl}+\mathrm{Ep} \pm$ Ank,Cal (And-Sil complexes) & \\
\hline Calc-silicates & Dol+Qu (or Tr+Cal) $\pm \mathrm{Hb} \pm \mathrm{Chl}+\mathrm{Czo}(\mathrm{Zo}) \pm \mathrm{Scp} \pm($ Grs-Adr) & $\mathrm{Hb}$ colorless \\
\hline
\end{tabular}


Table 2 continued

\begin{tabular}{|c|c|c|}
\hline Rock type & Paragenesis & Comment \\
\hline \multicolumn{3}{|c|}{ Andalusite-biotite-staurolite (6) and kyanite-biotite-staurolite (8) subfacies } \\
\hline Al-, K-metapelites & $\begin{array}{l}\mathrm{Qu}+\mathrm{St}+\mathrm{Ky}(\mathrm{And})+\mathrm{Bt}+\mathrm{Mu} \\
\mathrm{Qu}+\mathrm{St}+\mathrm{Gr}+\mathrm{Bt}+\mathrm{Mu}\end{array}$ & $\mathrm{Gr}_{0-25}$ \\
\hline \multirow[t]{2}{*}{ Mg-metapelites } & Qu+Bt+Ky+Mu \pm Crd (Ky-Sil complexes) & $\mathrm{Crd}_{85-100,} \pm \mathrm{Chl}_{70-100}$ \\
\hline & Qu+Bt+Crd+And+Mu (And-Sil complexes) & $\mathrm{Crd}_{70-100}, \pm \mathrm{Chl}_{70-100}$ \\
\hline \multirow[t]{2}{*}{ K-poor metapelites } & Qu+Gd+Ky+St (Ky-Sil complexes) & \\
\hline & $\begin{array}{l}\text { Qu+St+Crd+Gr+And (And-Sil complexes) } \\
\text { Qu+Cum+Gr+Gd }\end{array}$ & \\
\hline K-metasandstones & $\mathrm{Qu}+\mathrm{PI}+\mathrm{Bt}+\mathrm{Mu} \pm \mathrm{Kfs} \pm \mathrm{Gr}$ & \\
\hline Metasandstones & $\mathrm{Qu}+\mathrm{PI}+\mathrm{Bt}+\mathrm{Mu} \pm \mathrm{Gr} \pm \mathrm{Ep}$ & $\mathrm{Gr}_{0-25}$ \\
\hline \multirow[t]{2}{*}{ Metabasites } & $\begin{array}{l}\mathrm{Qu}+\mathrm{Pl}+\mathrm{Hb}+\mathrm{Gr}+\mathrm{Zo}(\mathrm{Ky}-\text { Sil complexes, subfacies 8) } \\
\mathrm{Qu}+\mathrm{PI}+\mathrm{Hb}+\mathrm{Gr}\end{array}$ & \multirow{2}{*}{$\begin{array}{l}\text { Hb blue-green, } \\
\mathrm{Gr}_{0-25} \\
\pm \mathrm{Mg} \text {-Chl, } \pm \mathrm{Ep}\end{array}$} \\
\hline & $\begin{array}{l}\mathrm{Qu}+\mathrm{Pl}+\mathrm{Hb} \pm \mathrm{Cum} \text { (And-Sil complexes) } \\
\mathrm{Qu}+\mathrm{PI}+\mathrm{Cum}\end{array}$ & \\
\hline Calc-silicates & $\mathrm{Tr}+\mathrm{Cal}+\mathrm{Qu}($ or $\mathrm{Cpx}) \pm \mathrm{Hb} \pm \mathrm{Czo}(\mathrm{Zo}) \pm \mathrm{Scp} \pm($ Adr-Grs $)$ & $\begin{array}{l}\text { Hb colorless, } \pm \mathrm{Chl} \\
\text { first } \mathrm{Cpx}(\mathrm{Di})\end{array}$ \\
\hline \multicolumn{3}{|c|}{ Sillimanite-biotite-staurolite subfacies (7) } \\
\hline Al-, K-metapelites & $\mathrm{Qu}+\mathrm{St}+\mathrm{Sil}+\mathrm{Gr}+\mathrm{Bt}+\mathrm{Mu} \pm \mathrm{PI}$ & $\mathrm{Gr}_{0-30}$ \\
\hline \multirow[t]{2}{*}{ Mg-metapelites } & $\mathrm{Qu}+\mathrm{Bt}+\mathrm{Sil}+\mathrm{Mu} \pm \mathrm{Crd}$ (Ky-Sil complexes) & $\pm \mathrm{Crd}_{80-100}$ \\
\hline & Qu+Bt+Crd+Sil+Mu (And-Sil complexes) & $\mathrm{Crd}_{65-100}$ \\
\hline \multirow[t]{2}{*}{ Metabasites } & $\mathrm{Qu}+\mathrm{PI}+\mathrm{Hb}+\mathrm{Gr}(\mathrm{Ky}-\mathrm{Sil}$ complexes, subfacies $7 b)$ & \\
\hline & $\begin{array}{l}\text { Qu+PI+Hb } \pm \text { Cum (And-Sil complexes, subfacies 7a) } \\
\text { Qu+PI+Cum }\end{array}$ & \\
\hline \multicolumn{3}{|c|}{ In other rock types, the parageneses are similar to subfacies 6 and 8} \\
\hline \multicolumn{3}{|c|}{ Chlorite-andalusite-garnet-cordierite zone 9a in low-T part of subfacies 9 up to chlorite disappearance } \\
\hline Al-, K-metapelites & $\mathrm{Qu}+\mathrm{And}+\mathrm{Mu} \pm \mathrm{Chl} \pm \mathrm{Crd} \pm \mathrm{Gr}, \mathrm{Qu}+\mathrm{Mu}+\mathrm{Chl}+\mathrm{Bt} \pm \mathrm{Gr}$ & \\
\hline Mg-metapelites & Qu+And+Crd+Chl+Mu & \\
\hline K-poor metapelites & $\begin{array}{l}\mathrm{Qu}+\mathrm{Crd} \pm \mathrm{Gr} \pm \mathrm{Chl}+\mathrm{Gd} \\
\mathrm{Qu}+\mathrm{Cum}+\mathrm{Chl}+\mathrm{Gd}(\text { Ant }) \pm \mathrm{Crd}\end{array}$ & \\
\hline K-metasandstones & $\mathrm{Qu}+\mathrm{PI}+\mathrm{Bt}+\mathrm{Mu} \pm \mathrm{Kfs}$ & \\
\hline Metasandstones & $\mathrm{Qu}+\mathrm{Pl}+\mathrm{Bt}+\mathrm{Chl}+\mathrm{Mu} \pm \mathrm{Ep}$ & \\
\hline Metabasites & $\mathrm{Qu}+\mathrm{Pl}+\mathrm{Hb} \pm \mathrm{Cum}+\mathrm{Chl}+\mathrm{Ep}$ & Hb blue-green \\
\hline \multicolumn{3}{|c|}{$\begin{array}{c}\text { Andalusite-biotite-muscovite (9), sillimanite-biotite-muscovite (10), } \\
\text { kyanite-biotite-muscovite (11) subfacies }\end{array}$} \\
\hline Al-, K-metapelites & $\begin{array}{l}\mathrm{Qu}+\mathrm{Ky}+\mathrm{Bt}+\mathrm{Mu}+\mathrm{Gr} \\
\mathrm{Qu}+\mathrm{And}(\mathrm{Sil})+\mathrm{Bt}+\mathrm{Mu}+\mathrm{Crd} \pm \mathrm{Gr}\end{array}$ & \\
\hline Mg-metapelites & $\mathrm{Qu}+\mathrm{Sil}(\mathrm{Ky}, \mathrm{And})+\mathrm{Bt}+\mathrm{Mu}+\mathrm{Crd}$ & \\
\hline \multirow[t]{2}{*}{ K-poor metapelites } & $\begin{array}{l}\text { Qu+Gd+Sil+Gr+Crd (Ky-Sil complexes, subfacies 10b) } \\
\text { Qu+Gd+Ky+Gr }\end{array}$ & \\
\hline & $\begin{array}{l}\text { Qu+Crd+Sil+Gr (And-Sil complexes, subfacies 10a) } \\
\text { Qu+Ant+And+Crd, Qu+Opx+Cum } \pm A n t \pm G r\end{array}$ & First Fe-Opx \\
\hline K-metasandstones & $\mathrm{Qu}+\mathrm{PI}+\mathrm{Bt}+\mathrm{Mu} \pm \mathrm{Gr} \pm \mathrm{Kfs}$ & \\
\hline Metasandstones & $\mathrm{Qu}+\mathrm{PI}+\mathrm{Bt}+\mathrm{Gr}+\mathrm{Mu} \pm \mathrm{Ep}$ & \\
\hline Metabasites & $\begin{array}{l}\text { Qu+Pl+Hb+Gr+Zo (Ky-Sil complexes, subfacies 11) } \\
\text { Qu+Pl+Hb+Gr (Ky-Sil complexes, subfacies 10b, 11) } \\
\text { Qu+PI+Hb } \pm \text { Cum (And-Sil complexes, subfacies 9, 10a) } \\
\text { Qu+PI+Cum (And-Sil complexes, subfacies 9, 10a) }\end{array}$ & $\mathrm{Hb}$ blue-green \\
\hline Calc-silicates & $\mathrm{Tr}+\mathrm{Cal}+\mathrm{Qu}$ (or Cpx $\pm \mathrm{Cal} \pm \mathrm{Tr}) \pm \mathrm{Hb} \pm \mathrm{Czo}(\mathrm{Zo}) \pm \mathrm{Scp} \pm(\mathrm{Adr}-\mathrm{Grs})$ & $\mathrm{Hb}$ colorless or pale green \\
\hline \multicolumn{3}{|c|}{$\begin{array}{c}\text { Biotite-sillimanite-orthoclase subfacies (14) } \\
\text { (subfacies 14a in And-Sil complexes and subfacies 14b in Ky-Sil complexes) }\end{array}$} \\
\hline Al-, K-metapelites & $\begin{array}{l}\text { Qu+Bt+Sil+Kfs } \\
\text { Qu+Bt+Sil+Gr } \pm \text { Kfs } \\
\text { Qu+Bt+Sil+Crd } \pm \text { Kfs or Gr }\end{array}$ & FeMg-Gr \\
\hline Mg-metapelites & $\mathrm{Qu}+\mathrm{Bt}+\mathrm{Sil}+\mathrm{Crd} \pm \mathrm{Kfs}$ & \\
\hline \multirow[t]{2}{*}{ K-poor metapelites } & Qu+Gr+Sil+Gd \pm Crd (Ky-Sil complexes, subfacies 14b) & \multirow{2}{*}{ Fe-Opx } \\
\hline & $\mathrm{Qu}+\mathrm{Opx}+\mathrm{Gr} \pm \mathrm{Gd} \pm \mathrm{Cum} \pm \mathrm{Crd}$ & \\
\hline K-metasandstones & $\mathrm{Qu}+\mathrm{PI}+\mathrm{Bt}+\mathrm{Kfs} \pm \mathrm{Gr}$ & \\
\hline
\end{tabular}


End of Table 2

\begin{tabular}{|c|c|c|}
\hline Rock type & Paragenesis & Comment \\
\hline Metasandstones & $\mathrm{Qu}+\mathrm{PI}+\mathrm{Bt} \pm \mathrm{Gr}$ & \\
\hline \multirow[t]{2}{*}{ Metabasites } & $\mathrm{Qu}+\mathrm{PI}+\mathrm{Hb}+\mathrm{Gr}$ (Ky-Sil complexes, subfacies 14b) & \multirow{2}{*}{$\begin{array}{l}\text { Hb green, brown-green } \\
\pm \mathrm{Cpx}, \mathrm{Opx}\end{array}$} \\
\hline & $\begin{array}{l}\mathrm{Qu}+\mathrm{Pl}+\mathrm{Hb} \pm \text { Cum (And-Sil complexes, subfacies 14a) } \\
\mathrm{Qu}+\mathrm{PI}+\mathrm{Cum}\end{array}$ & \\
\hline Calc-silicates & $\mathrm{Cpx}+\mathrm{Cal} \pm \mathrm{Pl} \pm \mathrm{Hb} \pm \mathrm{Dol} \pm \mathrm{Fo} \pm \mathrm{Scp} \pm(\mathrm{Grs}-\mathrm{Adr})$ & \\
\hline \multicolumn{3}{|c|}{ Biotite-andalusite-orthoclase subfacies (12) } \\
\hline Al-, K-metapelites & $\begin{array}{l}\text { Qu+Bt+And+Kfs } \\
\text { Qu+Bt+And+Crd } \pm \text { Kfs or Gr }\end{array}$ & \\
\hline Mg-metapelites & $\mathrm{Qu}+\mathrm{Bt}+\mathrm{Kfs}+\mathrm{And}+\mathrm{Crd}$ & \\
\hline K-poor metapelites & $\mathrm{Qu}+\mathrm{Ant}+\mathrm{And}+\mathrm{Crd} \pm \mathrm{Gr}$ & \\
\hline Metabasites & $\mathrm{Qu}+\mathrm{PI}+\mathrm{Hb} \pm \mathrm{Cum}, \mathrm{Qu}+\mathrm{PI}+\mathrm{Cum}$ & \\
\hline \multicolumn{3}{|c|}{ In other rock types, the parageneses are similar to subfacies 14} \\
\hline \multicolumn{3}{|c|}{ Biotite-kyanite-orthoclase subfacies (15) } \\
\hline Al-, K-metapelites & $\mathrm{Qu}+\mathrm{Bt}+\mathrm{Ky}+\mathrm{Gr} \pm \mathrm{Kfs}$ & \\
\hline Mg-metapelites & $\mathrm{Qu}+\mathrm{Bt}+\mathrm{Ky}+\mathrm{Crd} \pm \mathrm{Kfs}$ & \\
\hline K-poor metapelites & $\mathrm{Qu}+\mathrm{Gd}+\mathrm{Ky}+\mathrm{Gr}$ & \\
\hline Metabasites & $\mathrm{Qu}+\mathrm{PI}+\mathrm{Hb}+\mathrm{Gr}+\mathrm{Zo}, \mathrm{Qu}+\mathrm{PI}+\mathrm{Hb}+\mathrm{Gr}$ & \pm Cpx, Opx \\
\hline \multicolumn{3}{|c|}{ In other rock types, the parageneses are similar to subfacies 14} \\
\hline \multicolumn{3}{|c|}{ Granulite facies } \\
\hline \multicolumn{3}{|c|}{$\begin{array}{l}\text { Biotite-garnet-orthoclase-orthopyroxene subfacies (16) } \\
\text { (subfacies 16a in And-Sil complexes and subfacies 16b in Ky-Sil complexes) }\end{array}$} \\
\hline Al-, K-, Mg-metapelites & $\begin{array}{l}\text { Qu+Bt+Opx+Kfs } \pm G r \\
\text { Qu+Bt+Kfs } \pm G r \pm C r d \\
\text { Qu+Sil+Kfs } \pm G r \pm C r d\end{array}$ & $\begin{array}{l}\text { FeMg-Opx } \\
\text { FeMgAl-Bt }\end{array}$ \\
\hline K-poor metapelites & $\mathrm{Qu}+\mathrm{Opx} \pm \mathrm{Gr} \pm \mathrm{Crd}$ & \\
\hline \multirow[t]{2}{*}{ Metabasites } & $\begin{array}{l}\mathrm{Qu}+\mathrm{PI} \pm \mathrm{Hb}+\mathrm{Opx}+\mathrm{Gr}(\mathrm{Ky}-\text { Sil complexes, subfacies 16b) } \\
\mathrm{Qu}+\mathrm{Pl} \pm \mathrm{Hb}+\mathrm{Cpx}+\mathrm{Gr} \pm \mathrm{Opx}\end{array}$ & \multirow[t]{2}{*}{$\begin{array}{l}\text { Hb brown-green } \\
\text { FeMg-Opx }\end{array}$} \\
\hline & $\mathrm{Qu}+\mathrm{Pl} \pm \mathrm{Hb}+\mathrm{Cpx} \pm \mathrm{Opx}$ (And-Sil complexes, subfacies 16a) & \\
\hline Calc-silicates & $\mathrm{Cpx} \pm \mathrm{Cal} \pm \mathrm{Pl} \pm \mathrm{Hb} \pm \mathrm{Fo} \pm \mathrm{Wo} \pm \mathrm{Grs}-\mathrm{Adr}$ & \\
\hline \multicolumn{3}{|c|}{ Biotite-garnet-sillimanite-orthoclase subfacies (17) } \\
\hline Al-, K-, Mg-metapelites & $\begin{array}{l}\text { Qu+Bt+Sil+Gr } \pm \text { Kfs or Crd } \\
\text { Qu+Bt+Sil+Kfs } \\
\text { Qu+Bt+Opx+Kfs } \pm \mathrm{Gr}\end{array}$ & $\begin{array}{l}\text { FeMgAl-Bt } \\
\text { FeMg-Opx }\end{array}$ \\
\hline K-poor metapelites & $\mathrm{Qu}+\mathrm{Opx} \pm \mathrm{Gr} \pm \mathrm{Crd}$ & \\
\hline Metabasites & $\begin{array}{l}\mathrm{Qu}+\mathrm{Pl} \pm \mathrm{Hb}+\mathrm{Cpx}+\mathrm{Gr} \pm \mathrm{Opx} \\
\mathrm{Qu}+\mathrm{Pl} \pm \mathrm{Hb}+\mathrm{Opx}+\mathrm{Gr}\end{array}$ & $\begin{array}{l}\text { Hb brown-green } \\
\text { FeMg-Opx }\end{array}$ \\
\hline Calc-silicates & $\mathrm{Cpx} \pm \mathrm{Cal} \pm \mathrm{Pl} \pm \mathrm{Hb} \pm \mathrm{Fo} \pm \mathrm{Wo} \pm \mathrm{Grs}-\mathrm{Adr}$ & \\
\hline \multicolumn{3}{|c|}{$\begin{array}{l}\text { Garnet-cordierite-orthoclase-orthopyroxene subfacies (19) } \\
\text { (subfacies 19a in And-Sil complexes and subfacies 19b in Ky-Sil complexes) }\end{array}$} \\
\hline Al-, K-, Mg-metapelites & $\begin{array}{l}\text { Qu } \pm B t+O p x+K f s+C r d \pm G r \\
\text { Qu+Bt+Kfs } \pm \text { Crd } \pm G r \\
\text { Qu+Sil+Kfs } \pm C r d \pm G r\end{array}$ & $\begin{array}{l}\text { Mg-Opx } \\
\text { MgAl-Bt }\end{array}$ \\
\hline K-poor metapelites & $\mathrm{Qu}+\mathrm{Opx} \pm \mathrm{Gr} \pm \mathrm{Crd}$ & Mg-Opx \\
\hline \multirow[t]{2}{*}{ Metabasites } & $\begin{array}{l}\text { Qu+PI+Cpx+Gr } \pm \text { Opx (Ky-Sil complexes, subfacies 19b) } \\
\text { Qu+Pl+Opx+Gr }\end{array}$ & \multirow[t]{2}{*}{ FeMg-Opx } \\
\hline & Qu+PI+Cpx \pm Opx (And-Sil complexes, subfacies 19a) & \\
\hline Calc-silicates & $\mathrm{Cpx} \pm \mathrm{Cal} \pm \mathrm{Pl} \pm \mathrm{Hb} \pm \mathrm{Fo} \pm \mathrm{Wo} \pm \mathrm{Grs}-\mathrm{Adr}$ & \\
\hline \multicolumn{3}{|c|}{ Sillimanite-orthopyroxene subfacies (20) } \\
\hline Al-, K-, Mg-metapelites & $\mathrm{Qu} \pm \mathrm{Bt} \pm \mathrm{Kfs}+\mathrm{Sil}+\mathrm{Opx} \pm \mathrm{Gr}$ or $\mathrm{Crd}$ & $\begin{array}{l}\text { MgAl-Bt, Mg-Opx, Mg-Gr, } \\
\text { Mg-Crd }\end{array}$ \\
\hline K-poor metapelites & $\mathrm{Qu}+\mathrm{Opx} \pm \mathrm{Gr} \pm \mathrm{Crd}$ & Mg-Crd \\
\hline Metabasites & $\mathrm{Qu}+\mathrm{PI}+\mathrm{Cpx}+\mathrm{Gr} \pm \mathrm{Opx}, \mathrm{Qu}+\mathrm{PI}+\mathrm{Opx}+\mathrm{Gr}$ & FeMg-Opx, $\pm \mathrm{Hb}$ brown \\
\hline Calc-silicates & $\mathrm{Cpx} \pm \mathrm{Cal} \pm \mathrm{Pl} \pm \mathrm{Hb} \pm \mathrm{Fo} \pm \mathrm{Wo} \pm \mathrm{Grs}-\mathrm{Adr}$ & \\
\hline
\end{tabular}

Note. Subscript indexes at mineral abbreviations are $\mathrm{Mg} /(\mathrm{Mg}+\mathrm{Fe}) \mathrm{mol} . \%$ 
Sites of orogenic gold mineralization are shown according to [Raw Mineral Base of the Republic of Karelia, 2006; Eilu, 2012].

Archean metamorphism of the Karelian craton and its relict enclaves within the Svecofennian orogen (Fig. 2, 3) corresponds mostly to high T/P gradient conditions of the And-Sil facies series, suggesting high heat flow through the earth's crust at that time. The metamorphic grade of the Archean greenstone belts increases rapidly from their central parts (greenschist facies) toward the margins (low-T to medium-T amphibolite facies). The greenstone belts themselves are metamorphosed at a lower grade than their host TTG gneisses and migmatites, which were metamorphosed to the high-T amphibolite facies and, locally, even to the granulite facies. The Archean greenstone belts can be subdivided into two groups according to their metamorphic grade: (a) belts with predominant metamorphism up to medium-T amphibolite facies and (b) belts with predominant metamorphism to the greenschist facies. The first group is located mostly in the western part of the Karelian craton and seems to be spatially related to areas with granulite facies rocks. The second group is found at a considerable distance from granulites mostly in the east. The metamorphic regime of the Belomorian-Lapland orogen (Fig. 2, 3) was fundamentally different in the Archean and corresponded to the low T/P gradient conditions of the Ky-Sil facies series [Glebovitsky, 1973; Volodichev, 1990]. Evidence of this type of metamorphism is presented by remnants of high-P granulites of the West-Belomorian granulite belt [Glebovitsky, 1997] that are found in Proterozoic amphibolite facies rocks.

The pressure conditions of Paleoproterozoic metamorphism differ dramatically between discrete tectonic zones (Fig. 2, 4). During that time two paired metamorphic belts [Brown, 2010] were developed: (1) the Belomorian-Lapland collision orogen with low T/P gradient metamorphism of the Ky-Sil facies series [Glebovitsky, 1973, 1993; Volodichev, 1990; Glebovitsky et al., 1996; Volodichev et al., 2002] and (2) the Svecofennian accretionary orogen with high T/P gradient metamorphism of the And-Sil facies series [Sudovikov et al., 1970; Korsman et al., 1984; Glebovitsky, 1996, 1997; Korsman et al., 1999]. Also, Svecofennian low- to medium-T (occasionally high-T) high-P metamorphism of the Ky-Sil facies series locally overprinted Archean and Paleoproterozoic metamorphism along shear zones in the Karelian craton and, to a lesser extent, Paleoproterozoic metamorphism at the margin of the Svecofennian orogen.

The Belomorian-Lapland orogen, including the Lapland Granulite belt, is characterized by inverted metamorphic zoning, which is typical of collisional orogens. In the Svecofennian orogen, metamorphic zoning is closely connected with granitoid magmatism as is typical of accretionary orogens. Similar to the Archean greenstone belts, some of the Paleoproterozoic rift-related belts in the Karelian craton and Svecofennian orogen exhibit an increase in the metamorphic grade toward the margins.

The metamorphic area in question encompasses a part of the Sveco-Karelian zone (Fig. 2), which belongs to the Svecofennian accretionary orogen and hosts numerous sites with orogenic gold mineralization (Fig. 5). This zone is a reworked Archean continental margin recycled by Svecofennian accretionary processes in the Paleoproterozoic. The Paleoproterozoic high T/P gradient metamorphism of the And-Sil type and synmetamorphic or subsequent LT-LP hydrothermal-metasomatic processes that produced $\mathrm{Au}$ mineralization in shear zones, as is typical of the Svecofennian orogen, suggest fundamental controls by deepseated accretionary processes along the Archean continental margin. This type of relationships results in a spatial and genetic connection between orogenic gold mineralization and areas of high T/P metamorphism of the And-Sil type. These facts and considerations suggest certain specifics of the mantle plume evolution, the derivation and emplacement of magmatic melts at various crustal depths, and deep circulation of gold-bearing fluids, as is typical of continental margins of accretion type [e. g. Hronsky et al., 2012]. Relations between orogenic gold mineralization (Fig. 5) and LT-LP metamorphism and metasomatism in shear zones were controlled by transport properties of fluids and by P-T conditions favourable for mechanisms of gold precipitation from fluids. Consequently, the most promising exploration targets for orogenic gold deposits are areas of low-P And-type greenschist and low amphibolite facies [Bushmin, 1989, 1996; Bushmin et al., 2013]. Such areas are present in the Peräpohja belt, Kuusamo belt, and in the Kittilä area in Finland, in the Norrbotten area in Sweden, in the Kautokeino, Repparfjord, and Alta areas in Norway, in the Kuolajarvi area in Russia.

In contrast to the Sveco-Karelian zone of the Svecofennian orogen, the Karelian craton hosts not many sites with Archean and Proterozoic orogenic gold mineralization in Archean greenstone belts and Paleoproterozoic rift-related belts (Fig. 5). Among them there are only few sites with Archean orogenic gold in Finland (no Archean orogenic gold has yet been found in the Russian part) due to the following reasons. The grade of Archean metamorphism at most of the preserved Archean greenstone belts with shear zones is higher than the parameters of the greenschist facies. This 
means that the productive upper LT-LP parts of Archean shear zones were eroded and are not exposed any more at the surface. We suppose that this could be the reason for the scarce sites of economic Au mineralization in Archean shear zones of the Karelian craton.

Furthermore, Svecofennian high-P metamorphic-metasomatic processes superimposed on Archean and Paleoproterozoic metamorphic rocks along shear zones in greenstone and rift-related belts could play the role of an additional negative factor for gold mineralization. Yet, fluid-permeable shear zones accompanied by LT-LP metasomatism with gold mineralization were formed again at late-Svecofennian time [Glebovitsky et al., 2014]. The North Onega region in the Russian part of the Karelian craton is an example of a promising area for orogenic gold deposits [e. g. Borozdin et al., 2014] of late-Svecofennian age.

This investigation was financially supported by the Russian Foundation for Basic Research (S. A. Bushmin, Project 13-05-00393) and was carried out under the international Project «Fennoscandian Gold Transect» (headed by Raimo Lahtinnen, GTK, Espoo, Finland and Nikolai Philippov, State Company Mineral, St. Petersburg, Russia).

We thank Julio Gonzalez, Jan Sverre Sandstad, Dmitry V. Dolivo-Dobrovolsky, and Vasiliy I. Ivashenko for valuable discussions of scientific problems outlined in the paper. The authors acknowledge the helpful review comments and suggestions of Pekka Tuisku and Pentti Hölttä. The authors also thank Pentti Hölttä for supplying data on metamorphic rocks of Finland. Comments made by two anonymous reviewers substantially improved the paper. We are grateful to Galina $P$. Pleskach for drafting the figures.

\section{References}

Aranovich L. Ya., Berman R. G. Optimized standard state and solution properties of minerals: II. Comparisons, predictions, and applications. Contrib. Mineral. Petrol. 1996. Vol. 126. P. 25-37.

Ashley K. T., Law R. D. Modeling prograde $\mathrm{TiO}_{2}$ activity and its significance for Ti-in-quartz thermobarometry of pelitic metamorphic rocks. Contrib Mineral Petrol. 2015. 169:23.

Astafiev B. Y. Metasomatites of the metamorphic rocks of the Karelian megablock. 1996. PhD. Thesis. Leningrad. 21 p. (in Russian).

Baikova V. S., Lobach-Zhuchenko S. B., Levchenkov O. A., Cheekulaev V. P., Shuleshko I. K., Yakovleva $S$. Z. New data on the geological position and age of granulites of Karelia. Doklady AS USSR. 1984. Vol. 277, no. 2. P. 442-444 (in Russian).

Balagansky V. V., Glebovitsky V. A. Lapland granulite belt and complimentary structures. In Glebovitsky V. A. (ed.). Early Precambriam of the Baltic Shield. Leningrad: Nauka, 2005. P. 124-175 (in Russian).

Balagansky V. V., Kaulina T. V., Kislitsin R. V. Kolvitsa mélange and Umba terrain as a new type of Paleoproterozoic structures in northeast of the Baltic shield. In: Petrography of the $21^{\text {st }}$ century. Abstracts. Apatity. 2005. Vol. 3. P. 39-41 (in Russian).

Barbey P., Convert J., Martin H., Capdevila R., Hameurt J. Relationships between granite-gneiss terrains, greenstone belts and granulite belts in the $\mathrm{Ar}$ chean crust of Lapland (Fennoscandia). Geol. Rundsch. Bd. 1980. Vol. 69. P. 648-658.

Belyaev O. A., Bushmin S. A., Volodichev O. I., Glebovitsky V. A., Klein B. M., Kuleshevich L. V., Petrov V. P., Severin V. V. Metamorphic facies of the Eastern part of the Baltic Shield. Leningrad: Nauka, 1990. 141 p. (in Russian).

Belyaev O. A., Bushmin S. A., Voinov A. S., Volodichev O. I., Glebovitsky V. A. et al. Map of mineral facies of metamorphic rocks in the eastern Baltic Shield in the scale 1:1500 000 (ed. V. A. Glebovitsky). St. Petersburg: VSEGEI, IPGG RAS, 1991.

Bergh S. G., Kullerud K., Armitage P. E. B., Zwaan K. B., Corfu F., Ravna E. J. K., Myhre P. I. Neoarchaean to Svecofennian tectono-magmatic evolution of the West Troms Basement Complex, North Norway. Norwegian Journal of Geology. 2010. Vol. 90. P. 21-48.

Bergman S., Kübler L., Martinsson O. Description of regionalgeological and geophysical maps of northern Norrbotten County (east of the Caledonian orogen). Sveriges geologiska undersökning. 2001. Ba 56. 110 p.

Berman R. G. Thermobarometry using multiequilibrium calculations: a new technique with petrologic applications. Canadian Miner. 1991. Vol. 29. P. 833-855.

Berman R. G., Easton R. M., Nadeau L. A. New tectonometamorphic map of the Canadian shield: Introduction. Canadian Miner. 2000. Vol. 38. P. 277-285.

Bernard-Griffits J., Peucat J. J., Postaire B., Vidal Ph., Convert J., Moreau B. Isotopic date (U-Pb, Rb$\mathrm{Sr}, \mathrm{Pb}-\mathrm{Pb}$ and $\mathrm{Sm}-\mathrm{Nd}$ ) on mafic granulites from Finnish Lapland. Precambrian Res. 1984. Vol. 23. P. 325-348.

Bibikova E. V., Sheld T., Bogdanova S. V. et al. Geochronology of belomorides: interpretation of polystage geological history. Geochemistry. 1993. No. 10. P. 1393 1411 (in Russian).

Bibikova E. V., Slabunov A. I., Kirnozova T. I. et al. $\mathrm{U}-\mathrm{Pb}$ age of zircons from the rocks of the Keret' granite-greenstone system in the joint zone of Karelian and Belomorian structures of the Baltic shield. Doklady RAS. 1995. Vol. 343, no. 4. P. 517-521 (in Russian).

Bibikova E. V., Slabunov A. I., Bogdanova S. V., Sheld T. Tectono-thermal evolution of the Earth's crust in the Karelian and Belomorian provinces of the Baltic shield in the early Precambrian by $\mathrm{U}-\mathrm{Pb}$ isotope data for titanites and retiles. Geochemistry. 1999. No. 8. P. 1-15 (in Russian).

Bibikova E. V., Clyson S., Glebovitsky V. A. et al. Isotope dating of the Svecofennian stage of Belomo- 
rian belt transformation (Baltic shield). Geochemistry. 2001a. No. 10. P. 1023-1026 (in Russian).

Bibikova E., Skiöld T., Bogdanova S., Gorbachtschev R., Slabunov A. Titanite-rutile thermochronometry acrossthe boundary between the Archean Craton in Karelia and the Belomorian Mobile Belt, eastern Baltic Shield. Precambrian Res. 2001b. Vol. 105. P. 315-330.

Bibikova E. V., Bogdanova S. V., Glebovitsky V. A., Clyson S., Sheld T. Stages of evolution of the Belomorian mobile belt by U-Pb zircon geochronology (NORDSIM). Petrology. 2004. Vol. 12, no. 3. P. 227-244 (in Russian).

Borozdin A. P., Polekhovskii Yu. S., Bushmin S. A., Glebovitskii V. A., Belyatskii B. V., Savva E. V. Age of metasomatism and ore formation in the Srednyaya Padma vanadium-precious metals-uranium deposit (Karelia, Baltic Shield). Doklady Earth Sciences. 2014. Vol. 454. Part 1. P. 68-71.

Brown M. Metamorphism, Plate Tectonics, and the Supercontinent Cycle. Earth Science Frontiers, 2007. Vol. 14 (1). P. 1-18.

Brown M. Paired metamorphic belts revisited. Gondwana Research. 2010. Vol. 18. P. 46-59.

Brown $M$. The contribution of metamorphic petrology to understanding lithosphere evolution and geodynamics. Geoscience Frontiers. 2014. Vol. 5, no. 4. P. 553-569.

Bucher K., Frey M. Petrogenesis of metamorphic rocks. Springer. 2002. 341 p.

Bushmin S. A., Glebovitsky V. A. Scheme of mineral facies of metamorphic rocks. Geology of Ore Deposits. 2008. Vol. 50, no. 8. P. 659-669.

Bushmin S. A. Facies, facies series of metasomatism and ore speciation of metamorphic belts / In: Zharikov V. A. (ed.) Precambrian metasomatic rocks and their ore-bearing potential. Moscow: Akad. Nauk USSR, 1989. P. 46-64 (in Russian).

Bushmin S. A. Metasomatic rocks in the zones of regional metamorphism. In: Geologic research of metamorphic and metasomatic complexes. St. Petersburg: VSEGEI, 1996. P. 84-125 (in Russian).

Bushmin S. A., Dolivo-Dobrovolsky D. V., Lebedeva $Y u$. M. Infiltration metasomatism under conditions of granulite facies of high pressure (on the example of orthopyroxene-sillimanite rocks in the shear zones of the Lapland granulite belt). Doklady Earth Sciences. 2007. Vol. 412, no. 3. P. 383-387.

Bushmin S. A., Glebovitskii V. A., Savva E. V., Lokhov K. I., Presnyakov S. L., Lebedeva Yu. M., Sergeev $S$. A. The age of HP metasomatism in shear zones during collision related metamorphism in the Lapland Granulite Belt: The U/Pb SHRIMP II dates on zircons from sillimanite-hypersthene rocks of the Porya Guba nappe. Doklady Earth Sciences. 2009. Vol. 429, no. 8. P. $1342-1345$.

Bushmin S., Gonzalez J., Hölttä P., Sandstad J. S., Savva E. Metamorphism within the Fennoscandian Gold Transect (FENGOT) area of Fennoscandian Shield. In: Gold of the Fennoscandian Shield (Ed. A. I. Golubev). Proceedings of the international conference. Petrozavodsk: KarRC RAS, 2013. P. 19-21.

Chekulaev V. P., Baikova V. S. Granulite associations of grey gneisses of Western Karelia. In: Natural associa- tions of Archean grey gneisses (geology and petrology). Leningrad: Nauka, 1984. P. 141-150 (in Russian).

Daly S., Bogdanova S. Timing of the metamorphism in the Lapland granulite belt, Finland. Research Terrae. 1991. Ser. A. No. 5, 11.

Dobretsov N. L., Reverdatto V. V., Sobolev V. S., Sobolev N. V., Khlestov V. V. Metamorphic facies. Moscow: Nauka, Nedra, 1970. 432 p. (in Russian).

Dobretsov N. L., Sobolev V. S., Khlestov V. V. Facies of moderate-pressure regional metamorphism. Moscow: Nedra, 1972. 288 p. (in Russian).

Dobretsov N. L., Sobolev V. S., Sobolev N. V., Khlestov V. V. Facies of high-pressure regional metamorphism. Moscow: Nedra, 1974. 328 p. (in Russian).

Eilu P. (ed.) Mineral deposits and metallogeny of Fennoscandia. Geological Survey of Finland. Special Paper. 2012. No. 53. 401 p.

Eskola P. The mineral facies of rocks. Norsk. Geol. Tidsskr. 1920. Vol. 6. P. 143-194.

Eskola P. On the Granulites of Lapland. Amer. J. Sci. 1952. Vol. 5. P. 133-171.

Evins P. M., Laajoki K. Age of the Tokkalehto metagabbro and its significance to the lithostratigraphy of the early Proterozoic Kuusamo supracrustal belt, northern Finland. Bulletin of the Geological Society of Finland. 2001. Vol. 73. Parts 1-2. P. 5-15.

Frisch T., Jackson G. D., Glebovitsky V. A., Efimov M. M., Bogdanov M. N., Perrish P. P. Zircon U-Pb geochronology of the Kolvitsa gabbro-anorthosite complex, southern part of the Kola peninsular, Russia. Petrology. 1995. Vol. 3, no. 3. P. 248-254 (in Russian).

Fyfe W. S., Turner F. J., Verhoogen J. Metamorphic reactions and metamorphic facies. Moscow: Inostrannaya Literatura, 1962. 414 p. (in Russian).

Gaál G., Mikkola A., Söderholm B. Evolution of the Archean crust in Finland. Precambrian Res. 1978. Vol. 6, no. 2. P. 199-215.

Gerya T. V. P-T trends and the model of Precambrian granulite complexes formation. Dr. Sci. Thesis. Moscow, 1999. 36 p. (in Russian).

Glebovitsky V. A. The metamorphic facial series and the evolution of metamorphic belts. In.: The metamorphic belts of the USSR. Leningrad: Nauka, 1971. P. 269291 (in Russian).

Glebovitsky V. A. Problems of evolution of metamorphic processes in mobile regions. Leningrad: Nauka, 1973. 128 p. (in Russian).

Glebovitsky $V$. A. Mineral facies as criteria for evaluation of P-T parameters of metamorphism. In: Thermoand barometry of metamorphic rocks. Leningrad: Nauka, 1977. P. 5-39 (in Russian).

Glebovitsky V. A. Tectonics and regional metamorphism of the early Precambrian of the eastern part of the Baltic shield. Regional geology and metallogeny. 1993. Vol. 1. P. 7-24 (in Russian).

Glebovitsky V. A. Geological and physical-chemical relationship of metamorphism and tectonics in the early Precambrian. Geotectonics. 1996. Vol. 5. P. 27-42 (in Russian).

Glebovitsky V. A., Miller Y. V., Drugova G. M., Milkevich R. I., Vrevskii A. B. Structure and metamorphism of the Belomorian-Lapland collision zone. Geotectonics. 1996. Vol. 1. P. 63-75 (in Russian). 
Glebovitsky V. A. The early Precambrian of Russia. Harwood. Acad. Publ. 1997. 261 p.

Glebovitsky V. A., Zinger T. F., Belyatsky B. V. On the age of granulites of the West-Belomorian belt and nappe formation within it. Doklady RAS. 2000. Vol. 371. P. 163166 (in Russian).

Glebovitsky V. A. (ed.) Early Precambrian of the Baltic Shield. St. Petersburg: Nauka, 2005. 711 p. (in Russian).

Glebovitsky V. A., Bushmin S. A., Belyatsky B. V., Bogomolov E. S., Borozdin A. P., Savva E. V., Lebedeva $\mathrm{Yu}$. M. Rb-Sr Age of metasomatism and ore formation in the low-temperature shear zones of the Karelian craton, Baltic Shield. Petrology. 2014. Vol. 22, no. 2. P. 184-204 (in Russian).

Groves D. I., Goldfarb R. J., Gebre-Mariam M., Hagemann S. G., Robert F. Orogenic gold deposits: A proposed classification in the context of their crustal distribution and relationship to other gold deposit types. Ore Geology Reviews. 1998. Vol. 13. P. 7-27.

Hietanen $A$. On the facies serirs in various types of metamorphism. J. Geol. 1967. Vol. 75, no. 2. P. 187-214.

Holdaway M. J. Stability of andalusite and the aluminium silicate phase diagram. Amer. J. Sci. 1971. Vol. 271, no. 2. P. $97-131$.

Hölttä P., Paavola J. P-T-t development of Archean granulites in Varpaisjärvi, Central Finland. I. Effects of multiple metamorphism on the reaction history of mafic rocks. Lithos. 2000. Vol. 50. P. 97-120.

Hölttä P., Huhm H., Mänttäri I., Paavola J. P-T-t development of Archean granulites in Varpaisjärvi, Central Finland. II. Dating of high-grade metamorphism with the U-Pb and Sm-Nd methods. Lithos. 2000. Vol. 50. P. 121-136.

Hölttä P., Vaisanen M., Vaananen J., Manninen T. Paleoproterozoic metamorphism and deformation in Central Finish Lapland. In: Gold in the Central Lapland Greenstone Belt, Finland. Geological Survey of Finland. Special paper. 2007. Vol. 44. P. 9-44.

Hölttä P., Heilimo E., Huhma H., Juopperi H., Kontinen A., Konnunaho H., Lauri L., Mikkola P., Paavola J., Sorjonen-Ward P. Archean complexes of the Karelia Province in Finland. Geological Survey of Finland. Special Paper. 2012. Vol. 54. P. 9-20.

Hronsky J. M. A., Groves D. I., Loucks R. R., Begg G. C. A unified model for gold mineralisation in accretionary orogens and implications for regional-scale exploration targeting methods. Mineralium Deposita. 2012. Vol. 47. P. 339-358.

Idman H. Pre-Quarternary rocks, Sheet-1832-Ropi, Geological map of Finland 1:100 000. Geological Survey of Finland. 1988.

Käpyaho A., Hölttä P., Whitehouse M. U-Pb zircon geochronology of selected Neoarchean migmatites in eastern Finland. Bulletin of Geological Survey of Finland. 2007. Vol. 79, no. 1. P. 95-115.

Kivisaari T. Tuntsan metasedimenttivyöhykkeen matamorfoosi. (Ph. D. Thesis). University of Helsinki. 2008. 53 p. (in Finnish).

Koistinen T., Stephens M. B., Bogatchev V., Nordgulen Ø., Wennerström M., Korhonen J. (Comps.). Geological map of the Fennoscandian Shield 1:2 000000. Espoo; Trondheim; Uppsala; Moscow. 2001.
Kontinen A., Käpyaho A., Huhma H., Karhu J., Matukov D. I., Larionov A., Sergeev S. A. Nurmes paragneisses in eastern Finland, Karelian craton: provenance, tectonic setting and implications for Neoarchean craton correlation. Precambrian Res. 2007. Vol. 152. P. $119-148$.

Korikovsky S. P. Metamorphic facies of metapelites. Moscow: Nauka, 1979. 213 p. (in Russian).

Korikovsky S. P. Prograde transformations of gabbro-norites during eclogitization in the temperature range $600-700^{\circ} \mathrm{C}$. Russian Geology and Geophysics. 2005. Vol. 46, no. 12. P. 1352-1366 (in Russian).

Korikovsky S. P. Prograde transformations of medium-pressure amphibolites during their eclogitization. Petrology. 2009. Vol. 17, no. 4. P. 315-330.

Korikovsky S. P. Metamorphic transformations of metapelites, gneisses and granitoids under the conditions of eclogite facies. In: Modern problems of magmatism and metamorphism. 2012. Vol. 1. P. 291-294 (in Russian).

Korikovsky S. P. Mirčovski V., Zakariadze G. S. Metamorphic evolution and the composition of the protolith of plagioclase-bearing eclogite-amphibolites of the Buchim block of the Serbo-Macedonian Massif, Macedonia. Petrology. 1997. Vol. 5, no. 6. P. 534-549.

Korikovsky S. P., Somin M. L., Korsakov S. G. Highpressure symplectitic garnet-clinopyroxene-margaritemuscovite-clinozoisite amphibolites of the Dakhov Block, Northern Caucasus: genesis and composition of reaction textures. Doklady Earth Sciences. 2004. Vol. 397A, no. 6. P. 778-782.

Korikovsky S. P. Zakariadze G. S., Kolcheva K., Zhelyazkova-Panaiotova M. D., Solov'eva N. V. Albite-epidote-hornblende-bearing eclogite-amphibolites from the Belorechensk Uplift of the Rhodope Massif: Phase equilibria and P-T parameters. Doklady Earth Sciences. 1998a. Vol. 359A, no. 3. P. 360-363.

Korikovsky S. P., Zakariadze G. S., Kolcheva K., Zhelyazkova-Panaiotova M. D., Solov'eva N. V. Kataphorite eclogites of the Madan Tectonic Unit of the Crystalline Basement of the Eastern Rhodope. Doklady Earth Sciences. 1998b. Vol. 359A, no. 3. P. 372-375.

Korsman K., Hölttä P., Hautala T., Wasenius P. Metamorphism as an indicator of evolution and structure of the crust in eastern Finland. Geological Survey of Finland. 1984. Bulletin 328. 40 p.

Korsman K., Korja T., Papunen M., Virransalo P., GGT/SVEKA Working group. The GGT/SVEKA Transect: Structure and evolution of the continental crust in the Paleoproterozoic Svecofennian orogeny in Finland. Intern. Geol. Rev. 1999. Vol. 41. P. 287-333.

Kozlovskii V. M., Aranovich L. Ya., Frishman N. I. Prograde transformations of amphibolites into eclogites and eclogite-like rocks in the low-pressure field of the eclogite facies (by the example of the Belomorian Mobile Belt). Russian Geology and Geophysics. 2015. Vol. 56. P. 689-708.

Krill A. G. Svecokarelian thrusting with thermal inversion in the Karasjok-Levajok area of the northern Baltic Shield. Nor. Geol. Unders. 1985. Vol. 403. P. 89-101.

Kuleshevich L. V., Lavrov O. B. New data on the mineralogy of Karelia's gold units. In: Geology of Karelia 
from the Archaen to the present. Petrozavodsk: KarRC RAS. 2011. P. 149-160.

Laajoki K. The Himmerkinlahti member: an indicator of Intra-Karelian erosion within the early Proterozoic Kuusamo belt, Posio, Northern Finland. Bulletin of the Geological Society of Finland. 2000. Vol. 72. Parts 1-2. P. 71-85.

Lebedeva Yu. M., Bushmin S. A., Glebovitskii V. A. Thermodynamic conditions of metasomatism in hightemperature and high-pressure shear zones (Kandalaksha-Umba Zone, Kola Peninsula). Doklady Earth Sciences. 2012. Vol. 445. Part 1. P. 874-878.

Lobach-Zhuchenko S. B., Chekulaev V. P., Arestova N. A., Levsky L. K., Kovalenko A. V. Archean terrains of Karelia: their geological and isotope-geochemical grounds. Geotectonics. 2000. Vol. 6. P. 26-42 (In Russian).

Lobach-Zhuchenko S. B., Bibikova E. V., Drugov G. M. et al. Geochronology and petrology of the rocks of the magmatic complex of the Tupaya Guba area. Petrology. 1993. Vol. 1, no. 6. P. 657-677 (in Russian).

Lobach-Zhuchenko S. B., Levchenkov O. A., Chekulaev V. P., Krylov I. N. Geological evolution of the Karelian granite-greenstone terrain. Precambrian Res. 1986. Vol. 33. P. 45-65.

Mahar E. M., Baker J. M., Powell R. et al. The effect of Mn on mineral stability in metapelites. J. Metam. Geol. 1997. Vol. 15, no. 2. P. 223-238.

Mänttäri I., Hölttä P. U-Pb dating of zircons and monazites from Archean granulites in Varpaisjärvi, Central Finland: Evidence for multiple metamorphism and Neoarchean terrane accretion. Precambrian Res. 2002. Vol. 118. P. 101-131.

Marker M. Early Proterozoic thrusting of the Lapland granulite belt and its geotectonic evolution, northern Baltic Shield. Geol. Foren. Stockh. Forth. 1988. Vol. 11. P. 405-411.

Marker M., Henkel H., Lee M. K. Combined gravity and magnetic modelling of the Tanaelv and Lapland granulite belts, Polar profile, Northern Baltic Shield. In.: The European Geotraverse: integrative studies. European science foundation. 1990. P. 67-76.

Marker M. The Lapland Granulite Belt. Res. Terrae. 1991. Ser. A. No. 6. P. 40-66.

Miller Y. V., Milkevich R. I. Nappe-thrust structure of the Belomorian zone and its relation to the Karelian granite-greenstone region. Geotectonics. 1995. Vol. 6. P. 359-370 (in Russian).

Miller $Y . V$. Tectonics in the junction area between the Belomorian mobile belt and the Karelian craton. Geotectonika. 2002. Vol. 4. P. 14-28 (in Russian).

Mints M. V., Kaulina T. F., Konilov A. N., Krotov A. V., Stupak $V$. M. The thermal and geodynamic evolution of the Lapland granulite belt: Implications for the thermal structure of the lower crust during granulite-facies metamorphism. Gondwana Research. 2007. Vol. 12. P. 252-267.

Miyashiro A. Evolution of metamorphic belts. J. Petrol., 1961. Vol. 2, no. 3. P. 277-311.

Myskova T. A., Ivanov N. M., Korsakova M. A., Milkevich P. I., Presnyakov S. L., Berezhnaya N. G. Composition and age of volcanites of the Vermas unit of Sariolian, North Karelia. Stratigraphy. Geological Correlation. 2012. Vol. 20, no. 1. P. 3-17 (in Russian).
Pajunen M., Poutiainen M. Paleoproterozoic prograde metasomatic-metamorphic overprint zones in Archaean tonalitic gneisses. Eastern Finland. Bulletin of the Geological Society of Finland. 1999. Vol. 71, no. I. P. 73-132.

Powell R., Holland T. J. B., Worley B. Calculating phase diagrams involving solid solutions via non-linear equations, with examples using THERMOCALC. J. Metam. Geol. 1998. No. 16. P. 577-588.

Powell R., Holland T. J. B. On thermobarometry. J. Metam. Geol. 2008. No. 26. P. 155-179.

Räsänen J., Vaasjoki M. The U-Pb age of felsic gneiss in the Kuusamo schist area: reappraisal of local lithostratigraphy and possible regional correlations. In: Radiometric age determinations from Finnish Lapland and their bearing on the timing of Precambrian volcanosedimentary sequences. Geological Survey of Finland. 2001. Special Paper 33. P. 143-152.

Raw Mineral Base of the Republic of Karelia. Vol. 1. (Eds.: Mikhailov V. P., Aminov V. N). Petrozavodsk. 2006. 278 p. (in Russian).

Perchuk L. L., Krotov A. V., Gerya T. V. Petrology of amphibolites of the Tana belt and granulites of the Lapland complex. Petrology. 1999. Vol. 7, no. 4. P. 356-381 (in Russian).

Perchuk L. L., Gerya T. V., Van Reenen D. D., Smit C. A., Krotov A. V. P-T paths and tectonic evolution of shear zones separating high-grade terrains from cratons: examples from Kola Peninsula (Russia) and Limpopo Region (South Africa). Mineral. Petrol. 2000. Vol. 69. P. 109-142.

Perttunen V., Hansky E., Vaananen J., Eilu P., Lappalainen M. Rovaniemen kartta-allueen kalliopera. Geological Survey of Finland, Espoo, 1996. P. 1-63.

Sawyer E. W., Korneliussen A. The geochemistry of lower Proterozoic siliciclastic turbidites from the Rombak Window: implications for paleogeography and tectonic settings. Nor. geol. under. 1989. Bull. 415. P. 23-38.

Sedova I. S., Glebovitsky V. A., Semenov A. P. Evolution of metamorphism of late Archean periond in the Tupaya Guba area of Lake Kovdozero, northwest Belomorie. Petrology. 1996. Vol. 4, no. 2. P. 150-170 (in Russian).

Shemyakina N. M. Geochemistry of regional lowtemperature metasomatites of the eastern part of the Baltic Shield. PhD Thesis. Leningrad: VSEGEI, 1983. 20 p. (in Russian).

Skublov S. G., Astafiev B. Yu., Marin Yu. B., Berezin A. V., Melnik A. E., Presnyakov S. L. New data of the age of eclogites of the Belomorian mobile belt in Gridino area. Doklady RAS. 2011. Vol. 439, no. 6. P. 795-802 (in Russian).

Spear F. S. Metamorphic Phase Equilibria and Pressure-Temperature-Time Paths. Mineralogical Society of America, Washington, D. C., 1993. 799 p.

Sudovikov N. G., Glebovitsky V. A., Sergeev A. S. Geological evolution of deep zones of mobile belts (North Ladoga). Leningrad. 1970. 227 p. (in Russian).

Tinkham D. K., Zuluaga C. A., Stowell H. H. Metapelite phase equilibria modeling in MnNCKFMASH: The effect of variable $\mathrm{Al}_{2} \mathrm{O}_{3}$ and $\mathrm{MgO} /(\mathrm{MgO}+\mathrm{FeO})$ on mineral stability. Geol. Materials Res. 2001. Vol. 3, no. 1. P. 1-42. 
Tuisku P., Huhma H. Evolution of migmatitic granulite complexes: implications from Lapland Granulite Belt. Part 2: Isotopic dating. Geological Survey of Finland. 2006. Bulletin 78. P. 143-175.

Tuisku P., Mikkola P., Huhma H. Evolution of migmatitic granulite complexes: implications from Lapland Granulite Belt, Part I: Metamorphic geology. Geological Survey of Finland. 2006. Bulletin 78. P. 71-105.

Volodichev O. I. Belomorian complex of Karelia (geology and petrology). Leningrad: Nauka, 1990. 245 p. (in Russian).

Volodichev O. I. Amphibole - indicator of metamorphism of Lopian greenstone rocks. In: Mineralogy of magmatic and metamorphic rocks of the Precambrian in Karelia. Petrozavodsk: KarRC RAS, 1994. P. 105-117 (in Russian).

Volodichev O. I. Geologic-petrological features of the subduction stage of the Belomorian collision structure development in the upper Archean. In: Belomorian Mobile belt (geology, geodynamics, geochronology). Absracts. Petrozavodsk: KarRC RAS, 1997. P. 23-24 (in Russian).

Volodichev O. I. Map of metamorphism and transpressive tectonics of the Precambrian of Karelia in the 1:1000 000 scale. Report: Endogenic regimes of metamorphism in different geodynamic conditions of Precambrian of Karelia (authors: Volodichev O. I., Kuleshevich L. V., Kuzenko T. I.). Fondy IG KarRC RAS. Petrozavodsk. 2002. 185 p. (in Russian).

Volodichev O. I., Korol N. E., Kuzenko T. I., Sibelev O. S. Metamorphism of Early Precambrian complexes in the Eastern Fennoscandian shield. In: Geology of Karelia from the Archaen to the present. Petrozavodsk: KarRC RAS, 2011. P. 49-55 (in Russian).

Volodichev O. I., Kuleshevich L. V., Kuzenko T. I. Endogenic regimes of metamorphism in different geodynamic conditions of the Precambrian of Karelia. Fondy IG KarRC RAS. Petrozavodsk. 2002. 185 p. (in Russian).

Volodichev O. I., Slabunov A. I., Bibikova E. V. et al. Archean eclogites of the Belomorian mobile belt (Baltic shield). Petrology. 2004. Vol. 6. P. 609-631.

White R. W., Powell R., Holland T. J. B., Worley B. A. The effect of $\mathrm{TiO}_{2}$ and $\mathrm{Fe}_{2} \mathrm{O}_{3}$ on metapelitic assemblages at greenschist and amphibolite facies conditions: Mineral equilibria calculations in the system $\mathrm{K}_{2} \mathrm{O}-\mathrm{FeO}-\mathrm{MgO}-$ $\mathrm{Al}_{2} \mathrm{O}_{3}-\mathrm{SiO}_{2}-\mathrm{H}_{2}-\mathrm{Fe}_{2} \mathrm{O}_{3}$. J. Metam. Geol. 2000. Vol. 18, no. 5. P. 497-511.

Winkler H. D. F. Petrogenesis of metamorphic rocks. Springer-Verlag. 1976. 334 p.

\section{CONTRIBUTORS:}

\author{
Bushmin, Sergey \\ Institute of Precambrian Geology and Geochronology RAS \\ 2 Nab. Makarova, 199034 St. Petersburg, Russia \\ e-mail: s.a.bushmin@ipgg.ru \\ tel.: +79217561362; +7 (812) 3284701
}

Glebovitsky, Viktor

Institute of Precambrian Geology and Geochronology RAS 2 Nab. Makarova, 199034 St. Petersburg, Russia tel.: +7 (812) 3284701 